\title{
Pendidikan Islam: Analisis dari Perspektif Sejarah
}

\author{
Makmur Haji Harun \\ Universiti Pendidikan Sultan Idris (UPSI), Malaysia. \\ E-mail: makmur@fbk.upsi.edu.my
}

\begin{abstract}
Abstrak
Sejarah pendidikan pada dasarnya berawal dari rumah dan masjid sebagai pembekalan asas mengenai keIslaman. Sedangkan pendidikan sebagai warisan Islam pengukuhannya dimulai dari zaman Rasulullah SAW, berlanjut ke zaman Khulafau al-Rasyidin, Tabi'in, Tabi' tabi'in, kemudian masuk pada era terbentuknya madzhab-madzhab fikih pada abad ke-2 Hijriah dan seterusnya, pendidikan berkembang menurut jalur madzhab yang ada. Karena itu perkembangan madzhab bisa juga dianggap sebagai madrasah dan pondok pesantren. Pada masa ini puncak keilmuan mengerucut pada dua subjek kajian mendasar yaitu fikih dan ushul fikih. Pendidikan terus berjalan mengikut pola tertentu di dunia pendidikan Islam, berakar dari Madrasah Nizamiyah yang trennya mengarah kepada penggabungan empat madzhab dalam satu madrasah. Tetapi setelah masuknya penjajah ke negeri-negeri Muslim maka masuklah kurikulum pendidikan modern ke dunia Islam yang banyak melahirkan keragaman pola yang berdampak permasalahan serius di dunia Islam. Oleh karena itu, melalui tulisan ini kami mencoba mengangkat pendidikan ini sebagai warisan Islam dilihat dari perspektif sejarah yang panjang agar ianya dapat menjadi asas penting sebagai landasan tepat yang perlu diambil oleh kaum Muslimin selain dapat menghasilkan statemen pengajaran dan pembelajaran yang berwibawa dan berkualitas tinggi di balik tabir ungkapan sejarah dari zaman ke zaman.
\end{abstract}

Kata kunci: Pendidikan Islam dan perspektif sejarah.

\begin{abstract}
History education is basically originated from homes and mosques as provisioning principles regarding Islamization. While education as a legacy of Islam, the inauguration starts from the era Prophet Muhammad continues to era Khulafau al-Rasyidin, Tabi'in, Tabi' Tabi'in, then enter the era of jurisprudence understandings in the 2 nd century Hijriah and so on, developing education according to the existing madzhab pathways. Therefore, the development of madzhabs could also be considered as a madrasah and boarding school. At this time, the peak of scientific studies converging on two basic objects that fiqh and usul fiqh. Education continues to follow certain patterns in the Islamic education words, starting from Nizamiya Madrasah that trend leads to the incorporation of the four madzhabs in the madrasah. But after the arrival of colonists to Muslim countries and then start the modern educational curriculum into the Islamis world that delivered much diversity of patterns that impact a serious problem in the Islamic world. Therefore, this paper tried to study this as a legacy of Islamic education from the perspective of a long history that it is can be an important principle as the cornerstone of the right to be taken by the Muslims. In addition, it can generate statements of authoritative teaching and learning and high-quality behind the veil of history expression from period to period.
\end{abstract}

Keywords: Islamic education and historical perspective. 


\section{PENDAHULUAN}

Secara umum mengenai sejarah pendidikan dalam dunia Islam bisa dikatakan berawal dari proses pendidikan yang berlangsung di dalam rumah dan masjid. Namun harus diakui bahwa sejarah bermulanya pendidikan sebagai warisan Islam telah dimulai sejak Nabi Adam AS sehingga ke Nabi Muhammad SAW melalui dakwah ketauhidan para Nabi dan Rasul-Nya. Kemudian Nabi Muhammad sebagai khatamul anbiya telah meletakkan asas pola pendidikan yang kukuh sebagai pendidik ideal melalui fase Mekkah dan Madinah, berlanjut ke zaman para sahabat khulafa al-Rasyidin, berterusan ke periode Dinasti Umayyah, berkembang pada periode Abbasiyah, berkembang ke periode Khalifah Usmaniah, menjalar sehingga ke Sepanyol, Andalusia dan Sisilia.

Perkembangan pendidikan dalam Islam terus memasuki lembaga-lembaga kutub, sloon dan madrasah. Kurikulum dan pola pengembangan ilmu pengetahuan berdampak pada masa klasik dan zaman keemasan yang berpengaruh kepada transformasi dan kontribusi intelektual Islam terhadap dunia Barat. Pendidikan tersebut berlanjut sehingga pada era terbentuknya madzhab-madzhab fikih, abad ke-2 Hijriyah dan seterusnya, pendidikan yang mungkin bisa dikatakan sebagai pendidikan tinggi yang berkembang menurut jalur madzhab yang ada. Karena itu madzhab bisa juga diterjemahkan sebagai sekolah atau school of atau pondok pesantren (misalnya school of Syafi'i).

Pada masa ini puncak keilmuan mengerucut pada dua subjek kajian yaitu fikih dan ushul fikih. Proses pendidikan berjalan terus menerus di masjid-masjid, pada abad ke-5 Hijriyah, kurang lebih di era Imam Ghazali, muncul sebuah pola baru di dunia pendidikan Islam, bermula dengan Madrasah Nizamiyah yang didirikan oleh Nizamul Muluk. Sejak Nizamiyah, maka tren pendidikan Islam di peringkat tinggi mengarah kepada penggabungan empat madzhab dalam satu madrasah (seperti yang kita lihat di Univesitas al-Azhar Mesir era sekarang ini). Oleh karena itu, adanya perubahan pendidikan pada era Imam Ghazali (Nizamul Muluk). Pada masa itu terjadi masalah serius di dunia Sunni yang berpengaruh terhadap perkembangan pendidikan Islam dan aktivitas ortodoksi Sunni. Selain terjadi perselisihan madzhab yang sangat serius, sehingga ada kecenderungan saling mengkafirkan di antara madzhab, dan sering juga terjadi konflik berdarah yang disebabkan oleh perbedaan madzhab. Tampaknya pola pendidikan yang ada sebelumnya dengan mengikuti jalur madzhab tertentu, telah melahirkan fanatisme berlebihan.

Dampaknya juga berakibat kepada era kemunduran pendidikan dalam Islam setelah kehancuran Dinasti Abbasiyah, di tambah lagi pasca kejatuhan Baghdad, dan kemusnahan pengaruh Islam di Cordova. Walaupun pada akhirnya terbangun kembali setelah adanya teologi al-Ghazali dan madrasah dibentuk melalui Nizamul Muluk yang kemudian melahirkan perubahan positif, bahkan menjadi sebuah kebangkitan kembali Ahlu Sunah dari keterpurukan, selain adanya dikotomi ilmu pengetahuan dan peradaban Islam berterusan. Selain itu, munculnya para tokoh berpengaruh dalam dunia Islam serta usaha pembaharuan mereka dalam pendidikan, wujudnya gagasan Islamisasi ilmu pengetahuan, lahirnya pola dan kebijakan pendidikan Islam yang implikasinya juga dapat memperkukuh pendidikan Islam dari waktu ke waktu di berbagai tempat sehingga ke Nusantara.

Sementara perkembangan pendidikan pada era masuknya penjajah ke wilayah dan negeri kaum Muslim terutama di Nusantara, maka mulailah masuknya kurikulum pendidikan yang menggunakan sistem modern (sekuler) ke dunia Islam dengan banyak melahirkan berbagai cara dan pola mereka sehingga tidak sedikit menimbulkan masalah serius dalam dunia pendidikan Islam, terutama masalah akidah karena pendidikan 
bukan lagi hanya sekedar proses transfer ilmu dan teori dari mana-mana sumber, akan tetapi pendidikan sejati adalah berbentuk penanaman karakter unggul melalui pengamalan-pengamalan atas ilmu yang sudah dipelajari. Mendidik pula tidak hanya sebatas presentasi ngalor-ngidul bahkan pada perinsipnya mendidik akan lebih berkesan apabila dibarengi dengan pemberian teladan, Sesuai dengan pepatah Arab ada yang menyatakan bahwa "lisan al-hal aqwa min lisan al-maqal".

Di samping perjalanan panjang sejarah pendidikan tersebut dapat menjadi gambaran untuk mengungkap proses pengajaran dan pembelajaran yang telah diwarisi Islam dalam pentarbiyahan hidup kaumnya di muka bumi ini dari generasi ke generasi sehingga kini. Selain itu, pembasan mengenai pendidikan sebagai warisan Islam ini mengandungi beberapa ciri untuk dibicarakan secara panjang lebar yang dapat melengkapkan kesempurnaan dunia pendidikan dalam Islam, terutama dilihat dari perspektif sejarahnya. Kewujudan pengajaran dan pembelajaran ini dalam pendidikan Islam juga diharapkan agar dapat menempatkan wacana ini menjadi semakin menarik banyak penulis dan pengkaji, dalam mempertingkatkannya lagi sebagai asas pendidikan warisan Islam di negara Indonesia khususnya dan di Asia Tenggara umumnya.

\section{Definisi Dan Istilah}

Sebelum melanjutkan pembahasan ini, penulis perlu menghuraikan beberapa pengetian dan istilah terlebih dahulu. Pengertian pendidikan dapat dilihat dalam dua pengertian, iaitu pengertian secara etimologi $i^{1}$ dan terminologi $i^{2}$. Pengertian etimologi, kata didik lebih popular dan dikenal dengan istilah pendidikan yang mendapat imbuhan awalan dan akhiran pen-didik-kan menjadi kata pendidikan, yang berarti "perihal mendidik, pengetahuan mendidik, mengenai pengajaran, dsb" (Kamus Dewan edisi keempat, 2010: 350). Warisan berarti "sesuatu yang diwarisi, yang turun temurun, peninggalan berupa harta peninggalan atau harta pusaka" (Kamus Dewan edisi keempat, 2010: 1801). Islam pula mengandung kata salima berarti selamat, sentosa, damai, tunduk, patuh, dan berserah. Sementara aslama bermaksud berserah diri masuk dalam kedamaian (Maulana Muhammad Ali, (1980: 2). Sedangkan sejarah dapat diartikan sebagai "suatu peristiwa yang benar-benar berlaku pada waktu yang lampau, berupa kisah, riwayat, tambo dsb" (Kamus Dewan edisi keempat, 2010: 1411).

Pengertian terminologi perkataan pendidikan banyak digambarkan para ulama, ilmuan, intelektual, ahli dan pakar pendidikan, seperti pandangan-pandangan berikut. Pendidikan menurut Syed Naquib al-Attas (1992: 72) adalah "Pengenalan dan pengakuan yang secara berangsur-angsur ditanamkan ke dalam manusia tentang tempattempat yang tepat dari segala sesuatu di dalam tatanan penciptaan sedemikian rupa, sehingga hal ini membimbing ke arah pengenalan dan pengakuan tempat Tuhan di dalam tatanan wujud dan kepribadian." Islam pula dari segi istilah ia bermaksud tunduk dan patuh kepada perintah Allah SWT iaitu Tuhan pencipta dan pentadbir sekalian alam, dengan penuh rela dan bukan dengan paksaan atau perasaan terpaksa (Mohd Yusuf Ahmad, 2005: 4).

Menurut Harun Nasution (1979: 9) sebagai istilah (Islam sebagai agama) ialah bermaksud agama yang ajaran-ajarannya diwahyukan Tuhan kepada masyarakat manusia melalui Nabi Muhammad SAW sebagai Rasul. Islam pada hakekatnya membawa ajaran-ajaran yang bukan hanya mengenal satu segi, tetapi mengenai berbagai segi dari kehidupan manusia. Sedangkan menurut An-Najjar (1989) bahwa

${ }^{1}$ Etimologi adalah cabang ilmu bahasa mengenai asal usul perkataan. Kamus Dewan edisi baru. 1989. Kuala Lumpur: Dewan Bahasa dan Pustaka. hlm. 319.

${ }^{2}$ Terminologi iaitu mengenai (kata-kata) istilah. Ibid., hlm. 319. 
pendidikan Islam ialah pendidikan yang berasaskan kepada ajaran Islam yang merangkumi semua aspek. Ini termasuklah kurikulum, proses, sistem, kaedah, dan sebagainya. Ajaran Islam itu pula ajaran yang bersifat universal berasaskan kepada alQur'an dan as-Sunah. Hasan Langgulung (1981) pula melihatnya bahwa ini merupakan asas yang paling dasar. Di samping itu, mengambil kira juga kata-kata sahabat Rasulullah, pemikir-pemikir Islam, nilai kebiasaan masyarakat (al-'urf) dan kemaslahatan sosial.

Sementara menurut Abdul Halim El-Muhammady (1993: 14) yang membuat definisi pendidikan Islam sebagai;

"Proses mendidik dan melatih akal, jasmani, rohani dan emosi manusia berasaskan sumber wahyu al-Qur'an dan al-Sunah, pengalaman Salaf al-Shalih serta ilmuan muktabar untuk melahirkan insan shaleh yang mampu memikul tanggungjawab khalifah yang dipertanggungjawabkan oleh Allah SWT ke atas manusia supaya mengimarahkan alam ini untuk kebahagiaan hidupnya di dunia dan akhirat."

Dalam definisi lain Abdul Halim H. Mat Diah (1989: 44) mengatakan bahwa "Pendidikan Islam ialah proses yang dilalui anak didik dengan bimbingan yang dilakukan secara sengaja oleh pendidik untuk mencapai tujuan membentuk manusia muslim berdasakan ajaran Islam." Kemudian Burlian Somad (1989: 21) coba menjelaskan lagi konsep pendidikan Islam itu dengan membuat huraian yang lebih jauh katanya:

"Pendidikan Islam ialah aktivitas atau kegiatan yang bertujuan membentuk individu menjadi seorang yang mempunyai personalitas yang baik dan bernilai tinggi menurut kacamata Islam. Pendidikan Islan juga membentuk rasa anak didik menjadi halus dan tajam sehingga mampu mencintai Allah yang ghaib serta merasa sangat takut mendapat azab Allah, merasa bertanggungjawab untuk mengangkat darjah hidup kaum melarat dan anak-anak yatim, serta perasaan bertanggungjawab untuk membela agama Allah dengan rela mengorbankan apa saja yang dimiliki untuk keperluan perjuangan karena Allah."

Sementara konsep pendidikan secara menyeluuruh yang telah dirumuskan oleh muktamar at-Ta'limiyyah al-Islamiyyah ke-IV. Dalam salah satu rekomendasinya bahagian Ta'rif at-Ta'lim, dikemukakan bahwa:

"Makna yang lengkap bagi at-ta'lim (pendidikan) dalam pandangan yang Islami ialah apa yang tercakup dalam keseluruhan istilah attarbiyah, at-'ta'lim, dan at-ta'dib. Makna-makna yang terkandung pada seluruh istilah-istilah tersebut, yang berkaitan dengan manusia, masyarakatnya, lingkungannya, dan hubungannya dengan Allah adalah makna-makna yang saling berhubungan dan melengkapi satu sama lain. Semuanya menyusun lapangan pendidikan at-ta'lim dalam Islam, baik yang resmi maupun tidak resmi" (Makkah, 1983: 31).

Sedangkan pendidikan sebagai warisan Islam di sini mencakupi banyak bidang sebagaimana sejarah dapat diartikan sebagai "suatu peristiwa yang benar-benar berlaku pada waktu yang lampau, berupa kisah, riwayat, tambo dsb" (Kamus Dewan edisi keempat, 2010: 1411). Maka dalam kontek ini, tugas utama pendidikan agama dalam perspektif Islam adalah menciptakan sosok peserta didik berkepribadian paripurna (insan kamil). Untuk itu, menurut As-Syaibani (1975: 503), pelaksanaan pendidikan sebagai warisan Islam seyogianya lebih menekankan kepada aspek agama dan akhlak, di samping intelektual-rasional. Penekanannya bersifat menyeluruh dan memperhatikan 
seluruh potensi yang memiliki peserta didik, yang meliputi potensi intelektual, psikologi, sosial, dan spiritual secara seimbang dengan pelbagai ilmu pengetahuan lainnya (seni, pendidikan, jasmani, militer, teknik, bahasa asing, dan lainnya), sesuai dengan dinamika perkembangan zaman dan kebutuhan masyarakat di mana pendidikan tersebut dilaksanakan.

\section{Analisis dari Perspektif Sejarah Pendidikan Islam}

Pendidikan merupakan pembahasan penting dalam kehidupan manusia yang dapat diistilahkan sebagai life is education and education is life (Rupert C. Lodge, 1974). Pendidikan tidak akan punya arti apabila manusia tidak ada di dalamnya. Hal ini di sebabkan karena manusia merupakan subjek dan objek pendidikan tersebut. Menurut Muhammad Abduh (1972: 117), pendidikan yang baik adalah pendidikan yang dalam prosesnya mampu mengembangkan seluruh fitrah peserta didiknya, terutama fitrah akal dan agamanya. Dengan fitrah akal peserta didik akan dapat mengembangkan daya berfikir mereka secara rasional. Sementara melalui fitrah agama, akan tertanam pilarpilar kebaikan pada diri peserta didik yang kemudian terimplikasi dalam seluruh aktivitas hidupnya. Hurian tersebut akan diperincikan melalui sejarah panjangnya pendidikan Islam, seperti berikut:

\section{Realisasi Tarbiyah al-Aulad Sebagai Pendidikan Awal}

Sebelum membicarakan lebih lanjut tentang pendidikan awal dalam Islam, adalah lebih wajar kita memahami hakikat dan sifat agama ini. Islam adalah ciptaan Allah SWT dan diturunkan oleh Allah untuk hamba-hamba-Nya melalui Rasulullah SAW. Islam diturunkan dengan lengkap dan sempurna untuk membimbing manusia melaksanakan ubudiyah sepenuhnya kepada Allah SWT. Agama ini telah direalisasikan serta dihayati dengan sempurna oleh Rasulullah bersama-sama generasi pertama baik di dalam kehidupan individu maupun kehidupan bermasyarakat. Selanjutnya melalui Islam kita sadari bahwa ia merupakan agama yang merangkumi segala aspek kehidupan manusia termasuk bidang tarbawiyah dan ta'dibiyah. Hal tersebut dikarenakan jiwa manusia diciptakan Allah SWT bukanlah hanya untuk beribadat semata-mata, bahkan juga kepada perkara-perkara lain supaya membolehkan mereka meringankan beban dan pikirannya melalui proses hidup mereka. Seperti proses pendidikan merupakan aspek diperlukan dalam mencorakkan kehidupan mereka selagi ianya tidak melanggar batasbatas syariat yang telah ditentukan dalam ajaran Islam sesuai perintah Allah SWT dan tetap mengikut Sunnah Rasulullah SAW.

Berdasarkan surah al-'Ashr, didapati tiga bentuk pendidikan untuk membolehkan manusia selamat daripada kehinaan dan kerugian. Ini telah dijelaskan oleh Abdul Rahman an-Nawawi seperti berikut:

".....keselamatan manusia daripada kerugian dan azab dapat dicapai melalui tiga bentuk pendidikan berikut: Pertama, pendidikan individu yang membawa manusia kepada keimanan dan ketundukan kepada syariat Allah SWT, serta beriman kepada yang ghaib; Kedua, pendidikan diri yang membawa manusia kepada amal shaleh dalam menjalani kehidupan seharian; dan Ketiga, pendidikan masyarakat yang membawa manusia kepada sikap saling berpesan dalam kebenaran dan saling memberi kekuatan ketika menghadapi kesulitan yang pada intinya, semuanya ditujukan untuk beribadah kepada Allah SWT." 
Pendidikan Islam yang akan mencorakkan masyarakat Islam bukanlah sistem pendidikan berasaskan sesuatu yang asing daripada Islam, diimport dari Barat atau yang telah disempurnakan dengan memasukkan beberapa unsur Islam ke dalamnya karena sebagai contoh kebanyakan sistem yang ada ketandusan aspek-aspek kerohanian. Sesuatu sistem pendidikan hanya dapat dianggap sebagai sistem pendidikan Islam apabila segala prinsip, kepercayaan serta kandungannya berasaskan Islam. Pendidikan Islam terdapat dalam al-Qur'an adalah pendidikan yang menyeluruh, tidak terbatas kepada ibadat yang melupakan tingkah laku, atau memberatkan individu dan melupakan amal, tetapi meliputi segala kehidupan manusia. Pendidikan Islam berasaskan aqidah dan syariat Allah SWT. Kesyumulan Islam, seperti yang dijelaskan di atas terjelma dalam sistem atau manhaj pendidikan.

Pendidikan atau tarbiyah Islam dilaksanakan untuk mengembangkan tasawwur (konsep) dan kefahaman terhadap kehidupan berlandaskan al-Qur'an di dalam jiwa anak-anak. Asas dan teras sistem pendidikan ini adalah hakikat tauhid kepada Allah SWT. Di dalam al-Qur'an dan as-Sunah terdapat metodologi atau kaedah untuk mendidik manusia. Metodologi itu telah terbukti berkesan mendidik generasi awal. Rahsia utama kejayaan kaedah itu ialah memahami jiwa manusia yang tidak ubah bagaikan peti berkunci rapat, manakala memahami jiwa menjadi kuncinya. Sebenarnya sistem pendidikan yang paling berkesan dan mampu membawa perubahan menyeluruh dalam diri manusia adalah sistem pendidikan yang berupaya berbicara dengan jiwa. Sebenarnya hanya pendidikan Islam saja yang mempunyai metodologi tersebut dan mampu merawat jiwa manusia.

Dalam mendidik manusia, Islam memberikan penjelasan mengenai hakikat manusia, alam, penciptanya serta hubungan antara ketiga-tiganya. Keberkesanan dan keunggulan pendidikan Islam dalam membangunkan diri manusia adalah karena penjelasan mengenai perkara itu yang diperolehi daripada Allah SWT menerusi alQur'an. Kepincangan sistem-sistem pendidikan baik di Barat maupun di Timur adalah karena kekaburan dalam memahami perkara-perkara tersebut di atas. Pendidikan Islam boleh dibagikan kepada beberapa aspek yang merangkumi seluruh sisi kehidupan manusia. Aspek-aspek tersebut ialah: (a) Pendidikan kerohanian dan keimanan, (b) Pendidikan akhlak, (c) Pendidikan akal (d) Pendidikan jasmani. Sedangkan pendidikan keimanan bermaksud memperkenalkan kepada anak-anak dengan unsur-unsur keimanan, membiasakan dirinya dengan rukun Islam serta mendidiknya dengan prinsipprinsip syariat yang mulia sejak usia tamyiz (berakal) lagi. Yang dimaksudkan dengan unsur-unsur keimanan ialah semua perkara berkaitan dengan hakekat keimanan serta perkara-perkara ghaib seperti beriman kepada Allah, malaikat, kitab-kitab-Nya, Rasul dan dengan rukun iman lainnya.

Dalam sistem pendidikan Islam, unsur alam digunakan untuk menyadarkan hati dalam melahirkan perkara-perkara di atas. Terdapat banyak ayat al-Qur'an yang menyentuh mengenai alam bagi membangunkan kepekaan hati manusia. Al-Qur'an membangunkan indera manusia untuk mengenal Tuhannya, melihat kekuasaan-Nya di dalam benda-benda baik yang kecil maupun yang besar, benda yang mudah atau yang kompleks. Semuanya membuktikan kekuasaan dan keperkasaan Allah SWT serta keagungan dan kehebatan kreativitas-Nya. Al-Qur'an mendidik akal dan hati sekaligus secara bersamaan, hanya dengan sentuhan ke atas akal dan hati, akan terbangunlah akidah yang mantap dan sahih.

Sistem pendidikan Barat mungkin mampu untuk menghasilkan anak-anak pintar cerdas dan merealisasikan potensi aqli dan jasmaninya karena memang itu tujuan pendidikan mereka. Walaupun penekanan moral diberi ruang dalam sistem ini, sistem 
moral bukan Islam sudah pasti tidak dapat menghasilkan sistem moral Islam, sekalipun kita berusaha untuk menempelkan kekurangannya dengan menggabungkan unsur-unsur Islam ke dalamnya. Muhammad Iqbal pernah mencatatkan: "Sistem pendidikan Barat mampu membawa anak-anak kita mengkagumi dan mempelajari kemajuan teknologi, tetapi tidak bagi mendidik mata anak-anak untuk menangisi dosa-dosanya dan mendidik hati mereka supaya takut hanya kepada Penciptanya". Sebenarnya terdapat perbezaan yang besar antara mengambil kaedah pengajaran dan pembelajaran berdasarkan pendekatan tokoh-tokoh Barat dengan mengambil sistem pendidikannya.

Oleh karena itu, kita boleh dan sewajarnya memanfaatkan kajian-kajian yang dijalankan oleh Barat, terutama dalam bidang latihan keterampilan hidup seperti membaca, menulis, dan mengira. Begitu juga dengan kajian mereka mengenai teknik berfikir dan pembangunan jasmani. Bagaimanpun, yang dibimbangi ialah kita mengambil seluruh sistem pendidikan yang mereka kemukakan, karena ini akan merusakkan lantaran tujuan dan falsafah pendidikan mereka yang tidak berasaskan tauhid dan keimanan. Sistem Barat hanya mampu melahirkan anak-anak yang pintar tetapi jiwa tetap kosong. Yang lebih membimbangkan ialah lahir tasawwur yang terpisah antara aspek kerohanian dan moral dengan aspek-aspek pendidikan lain. Pendekatan segolongan Muslim yang berpegang kepada sistem Barat dan cuba memperbaiki kekurangannya dengan memasukkan unsur-unsur Islam juga tidak banyak membantu, malah akan mengelirukan masyarakat Islam. Langkah-langkah ini tidak jauh bedanya dari pendekatan pendidikan sekuler yang wujud pada hari ini.

Demikian pula perkembangan seterusnya, pengaruh al-Qur'an dan as-Sunnah kepada umat Islam melalui pendidikan yang khas dikenali dengan tarbawiyah atau ta'dibiyah sehingga hal tersebut dapat mempengaruhi kehidupan dan peradaban masyarakat Islam tersebut terus meluas sehingga mempengaruhi juga perkembangan proses pengajaran dan pembelajarannya di Nusantara, menjadikan kesannya memasuki struktur sosial kehidupan masyarakat dalam semua lapisan. Dampak pengaruh pendidikan Islam tersebut dapat melahirkan kesabaran dan ketekunan yang seterusnya akan tumbuh rasa ingin memperbesar dan mengagungkan pencipta-Nya, karena melalui pendidikan dapat mendekatkan diri seseorang kepada Allah SWT sebagai penciptanya. Kemudian akan melahirkan hubungan baik antara manusia dengan Allah SWT dan dapat menjalinkan keakraban antara sesama manusia sehingga terungkap muamala ma'aAllah wa muamalah ma'annas.

Dari kenyataan tersebut maka dapat digambarkan bahwa dalam etika pendidikan para sahabat sangat menjaga akhlak mereka. Selain itu dapat mewujudkan jalinan akidah, ibadat, dan akhlak secara bersamaan. Maka cara ini merupakan proses pendidikan jasadiah yang harus dialami untuk menghidupkan budaya akidah yakni dengan menanamkan dalam hati sanubari tentang kepercayaan kepada Allah SWT dengan baik dan bijaksana agar mudah menjalankan segala perintah dan meninggalkan segala larangan-Nya. Manakala ibadat juga merupakan proses pendidikan ruhiyah yang ada dalam Islam agar dapat mengajar manusia supaya tunduk dan ta'at serta patuh kepada perintah dan kasih sayang yang mesti dilaksanakan dengan penuh keikhlasan dalam hidup serta kehidupan mereka di dunia dan akherat.

\section{Konsep Pendidikan Islam Era Rasulullah SAW Fase Mekkah dan Madinah}

Sebelum membicarakan konsep pendidikan dari sumbernya sebagai seorang utusan dari Allah SWT, maka perlu melihat profil Baginda sebagai pendidik ideal dalam pengelola dan pengembangkan pendidikan Islam di garda terdepan bersama para sahabat Baginda. Tanpa keberadaan pendidiknya, proses pendidikan tidak berarti apa- 
apa. Untuk mewujudkan pendidik professional berdasarkan roh Islam, perlu melihat sisi kehidupan Rasulullah SAW sebagai seorang pendidik ideal, karena hakekat diutusnya baginda ke atas muka bumi ini adalah sebagai uswah al-hasanah dan rahmatan li alalamin. Semua sunah Rasulullah menjadi panduan utama setelah al-Qur'an dan asSunah membicarakan segala aspek kehidupan manusia terutama aspek pendidikan. Keberadaannya sebagai pendidik yang juga merupakan konsep pendidikan yang kebenarannya tidak diragukan lagi karena langsung direkomendasikan oleh Allah SWT kepada kaumnya.

Konsep pendidikan Islam di era Rasulullah SAW sebagai pendidik pertama dan terutama dalam dunia pentarbiyahan. Proses transformasi ilmu pengetahuan, internalisasi nilai-nilai spiritualisme dan bimbingan emosional yang dilakukan Baginda dapat dikatakan sebagai mukjizat luar biasa, yang manusia apa dan di mana pun tidak dapat melakukan hal yang sama. Dan hasil pendidikan Islam periode Rasulullah tersebut menjadi konsep asas yang telah terbukti kinerjanya melalui kemampuan murid-murid Baginda (para sahabat) yang hebat dan luar biasa. Misalnya saja Umar bin Khattab menjadi ahli hukum dan pemerintahan, Abu Hurairah sebagai ahli Hadis, Salman al-Farisi dikenal sebagai ahli perbandingan agama (Majusi, Yahudi, Nasrani, dan Islam), dan Ali bin Abi Thalib juga mejadi ahli hukum dan tafsir alQur'an. Kemudian murid dari para sahabat Rasulullah di kemudian hari berlanjut sehingga ke tabi'in, tabi'-tabi'in dan seterusnya banyak menjadi ahli dan pakar dalam berbagai-bagai bidang ilmu pengetahuan, sains, tekhnologi, astronomi, filsafat, tasawuf dan lain sebagainya yang mampu menghantarkan Islam ke pintu gerbang zaman keemasan terutama pada fase awal kekuasaan dinasti Abbasiyah.

Gambaran dan pola konsep pendidikan Islam di periode Rasulullah SAW juga dikenal dengan fase Mekkah dan Madinah merupakan sejarah masa lalu yang perlu diungkapkan kembali sebagai bahan perbandingan, sumber gagasan, gambaran strategi untuk menyukseskan pelaksanaan proses pendidikan Islam. Konsep pendidikan Islam di masa Rasulullah SAW tidak terlepas dari metode evaluasi, materi, kurikulum, pendidik, peserta didik, lembaga, dasar, tujuan dan sebagainya yang pertalian dengan pelaksanaan pendidikannya berjalan secara teoritis dan praktis. Menurut Ahmad M. Saefuddin (1998: 166) bahwa "Untuk dapat memahami misi Muhammad SAW sebagai pendidik dan rahmat bagi sekalian alam, harus menoleh ke belakang, mempelajari sejarah keadaan masyarakat manusia menjelang kelahiran Nabi Muhammad SAW sehingga jelas wujud sebenarnya rahmat itu. Oleh karena itu, perlu mengungkapkan sejarahnya bersumberkan al-Qur'an beserta tafsirnya, keterangan-keterangan dari Hadis Nabi, atsar para sahabat, kitab-kitab, dan buku-buku yang disusun oleh para ahli sejarah." Kalau kajian tersebut sudah dilengkapkan maka akan menemukan bagaimana konsep dan pola pendidikan yang telah dilakukan oleh Rasulullah SAW sejalan dengan tahapan-tahapan dakwah yang disampikannya kepada kaum Quraisy.

Ada tiga tahapan proses awal pendidikan yang Rasulullah terapkan ketika bermulanya dakwah baginda kepada kaumnya di Mekkah dan Madinah. Pertama, tahap rahasia dan perorangan. Pada awal turunnya wahyu pertama al-Qur'an surah al-'Alaq ayat 1-5, pola pendidikan yang dilakukan Nabi adalah secara sembunyi-sembunyi, mengingat kondisi sosio politik masyarakat Mekkah ketika itu yang belum stabil, maka dimulai dari diri Baginda sendiri dan keluarga dekatnya. Mula-mula Rasulullah mendidik istrinya Khadijah untuk beriman dan menerima petunjuk-petunjuk Allah, kemudian diikuti oleh sepupunya Ali ibn Abi Thalib (anak pamannya Abi Thalib) dan Zaid ibn Haritsah (seorang pembantu Baginda), kemudian diikuti sahabat karibnya Abu Bakar as-Siddiq. Kemudian secara berangsur-angsur ajakan tersebut disampaikan secara 
meluas, tetapi masih terbatas di kalangan keluarga dekat dari suku Qurasy saja, seperti Usman bin Affan, Zubai bin Awwam, Sa'ad bin Waqas, Abdurrahman bin Auf, Thalhah bin Ubaidillah, Abu Ubaidillah bin Jahrah, Arqam bin Arqam, Fatimah binti Khattab, Said bin Zaid, dan beberapa orang dekat lainnya, mereka semua yang menerima ajakan Nabi pada tahap awal ini disebut sebagai Assabiquna al-awwalun yakni orang-orang yang mula-mula masuk Islam. Adapun lembaga pendidikan dan pusat kegiatan proses pengajaran dan pembelajaran pendidikan Islam pertama kali di era awal ini adalah rumahnya Arqam bin Arqam (Haekal, 1972: 30-2).

Kedua, tahap terang-terangan. Pendidikan secara sembunyi-sembunyi berlangsung selama tiga tahun, sampai turun wahyu berikutnya yang memerintahkan dakwah secara terbuka dan terang-terangan (al-Qur'an, 22: 213-216). Ketika wahyu tersebut turun, Baginda mengundang keluarga dekatnya utuk berkumpul di Bukit Shafa, menyerukan agar berhati-hati terhadap azab yang keras di hari kemudian (hari kiamat); bagi orang yang tidak mengakui Allah sebagai Tuhan Yang Esa dan Muhammad sebagai utusan-Nya. Seruan tersebut dijawab oleh Abu Lahab, "Celakalah kamu Muhammad! Untuk inikah kamu mengumpulkan kami? Maka ketika itulah diturunkan wahyu yang menjelaskan perihal Abu Lahab dan istrinya (al-Qur'an, 111:1-5). Kemudian perintah dakwah secara terang-terangan dilakukan oleh Rasulullah SAW, seiring dan sejalan dengan jumlah sahabat yang semakin banyak dan untuk meningkatkan jangkauan seruan dakwah, karena diyakini dengan dakwah tersebut banyak kaum Quraisy yang akan masuk Islam. Di samping itu, keberadaan rumah Arqam ibn Arqam sebagai pusat dan lembaga pendidikan Islam sudah diketahui oleh kaum kuffar al-Quraisy.

Ketiga, tahap untuk umum. Hasil seruan dakwah secara terang-terangan yang terfokus kepada keluarga dekat, kelihatannya belum maksimal sesuai dengan apa yang diharapkan. Maka, Rasulullah mengubah strategi dakwahnya dari seruan terfokus kepada keluarga dekat beralih kepada seruan untuk umum yakni umat manusia secara keseluruhan. Seruan dalam skala 'internasional' tersebut didasarkan kepada perintah Allah surah al-Hajr ayat 94-95. Sebagai tindak lanjut dari perintah tersebut, maka pada musim haji Rasulullah mendatangi kemah-kemah para jama'ah haji. Pada awalnya tidak banyak yang menerima kecuali sekelompok jama'ah haji dari Yatsrib, kabilah Khazraj yang menerima dakwah secara antusias. Bermula dari sinilah sinar Islam mulai memancar ke luar Mekkah (Soekarno dan Ahmad Supadi, 1990: 32).

Penerimaan masyarakat Yatsrib terhadap ajaran Islam secara antusias tersebut, dikarenakan beberapa faktor: (1) adanya khabar dari kaum Yahudi akan lahirnya seorang Rasul; (2) suku Aus dan Khazraj mendapat tekanan dan ancaman dari kelompok Yahudi; (3) konflik antara Khazraj dan Aus yang berkelanjutan dalam rentang waktu yang sudah lama, oleh karena itu mereka mengharapkan seorang pemimpin yang mampu melindungi dan mendamaikan mereka. Berikutnya, di musim haji pada tahun kedua belas kerasulan Muhammad SAW., Rasulullah didatangi dua belas orang laki-laki dan seorang wanita untuk berikrar kesetiaan yang dikenal dengan "Bai'ah al-'Aqabah I." Mereka berjanji tidak akan menyembah selain kepada Allah SWT, tidak akan mencuri dan berzina; tidak akan membunuh anak-anak, dan menjauhkan perbuatan-perbuatan keji serta fitnah, selalu taat kepada Rasulullah dalam yang benar; dan tidak mendurhakainya terhadap sesuatu yang mereka tidak inginkan (Syafiyyur Rahman al-Mubarakfury, 2000: 109).

Berkat semangat tinggi yang dimiliki para sahabat dalam mendakwahkan ajaran Islam, sehingga seluruh penduduk Yatsrib masuk Islam kecuali orang-orang Yahudi. Musim haji berikutnya ada 73 orang jama'ah haji dari Yatsrib mendatangi Rasulullah, 
berikrar akan selalu setia dan melindungi Rasulullah SAW dan menetapkan keimanan kepada Allah dan Rasul-Nya di tempat yang sama dengan pelaksanaan "Bai'ah al'Aqabah I" tahun lalu yang dikenal dengan "Bai'ah al-'Aqabah II, dan mereka bersepakat akan memboyong Rasulullah ke Yatsrib. Inilah bentuk dakwah Rasulullah secara umum, dakwah kepada setiap umat manusia yang datang dari seluruh penjuru bumi berhaji ke Mekkah.

Demikianlah tiga tahapan proses dakwah yang telah diasaskan oleh Rasulullah SAW menjadi konsep utama pendidikan Islam yang menjadikan al-Qur'an sebagai kurikulum pendidikan diwahyukan Allah SWT kepada Rasulullah SAW sesuai dengan kondisi dan situasi, serta sesuai kejadian dan peristiwa yang dialami umat Islam saat itu. Oleh karena itu, dalam prakteknya tidak saja logis dan rasional tetapi juga secara fitrah dan pragmatis. Hasil dari cara demikian itu dapat dilihat dari sikap rohani dan mental para pengikutnya yang dipancarkan ke dalam sikap hidup mereka yang bermental dan bersemangat tangguh, tabah, dan sabar tetapi aktif dalam memecahkan masalah yang dihadapinya. Dalam perkembangan sejarah selanjutnya ternyata mereka ini merupakan kader inti mubaligh dan pendidik pewaris Nabi yang brilian dan militan dalam menghadapi segala tantangan atau cobaan dalam hidup dan kehidupan mereka (Soekarno dan Ahmad Supadi, 1990: 31).

\section{Pola Pendidikan Islam pada Masa Khulafau al-Rasyidin}

Pada masa Rasulullah SAW, negara Islam meliputi seluruh jazirah Arab dan pendidikan Islam berpusat di Madinah, setelah Rasulullah wafat maka kekuasaan pemerintahan dipegang oleh Khulafau al-Rasyidin dan wilayah Islam telah meluas di luar dari jazirah Arab. Para khalifah ini memusatkan perhatiannya kepada pendidikan, syiarnya agama, dan kekokohan Negara. Terutama setelah Abu Bakar as-Siddiq dilantik sebagai pemimpin menggantikan Nabi untuk melanjutkan tugas-tugas sebagai pemimpin agama dan pemerintahan (Badri Yatim, 2001: 36). Masa awal kekhalifahan Abu Bakar diguncang pemberontakan oleh orang-orang murtad, orang-orang yang mengaku sebagai nabi dan orang-orang yang enggan membayar zakat. Berdasarkan hal ini Abu Bakar memusatkan perhatiannya untuk memerangi para pemberontak yang dapat mengacaukan keamanan dan ditakutkan dapat mempengaruhi orang-orang Islam yang masih lemah keimanannya sehingga memungkinkan menyimpang dari ajaran Islam.

Untuk mengatasi keadaan tersebut, maka dikirimlah pasukan untuk menumpas para pemberontak di Yamamah. Dalam penumpasan pemberontak ini banyak umat Islam gugur dalam peperangan, tidak terkecuali dari sahabat dekat Rasulullah dan para hafiz al-Qur'an sehingga mengurangi jumlah sahabat yang masih hafal al-Qur'an. Oleh karena itu, Umar bin Khattab menyarankan kepada khalifah Abu Bakar untuk mengumpulkan ayat-ayat al-Qur'an, kemudian untuk merealisasikan saran tersebut diutuslah Zaid bin Tsabit untuk mengumpulkan semua tulisan al-Qur'an dari berbagai tempat dan bahan sebagai cara untuk mempermudah pengajaran dan penulisannya. Adapun pola pendidikan yang diterapkan pada masa khalifah Abu Bakar tidak jauh berbeda dengan pendidikan pada masa Rasulullah SAW baik materi maupun lembaga pendidikannya (Hanun Asrohah, 2001: 36).

Sedangkan dari sisi materi pendidikan Islam yang diterapkan pada masa Abu Bakar ialah terdiri dari pendidikan tauhid atau keimanan, akhlak, ibadah, kesehatan, dan lain sebagainya. Adapun cakupan pendidikan keimanan iaitu menanamkan bahwa satusatunya yang wajid disembah hanyalah Allah SWT. Pendidikan akhlak pula seperti adab masuk rumah orang, sopan santun bertetangga, bergaul dalam masyarakat, dan 
lain-lainnya. Pendidikan ibadah pula membahas tentang pelaksanaan shalat, puasa, haji dan lain sebagainya. Adapun pendidikan kesehatan juga seperti pendidikan yang lain membahas tentang kesehatan, gerak gerik dalam shalat merupakan didikan untuk memperkuat jasmani dan rohani (Mahmud Yunus, 1989: 18).

Setelah Abu Bakar menyaksikan sendiri berbagai persoalan yang timbul di kalangan kaum muslimin setelah Nabi wafat, berdasarkan hal inilah Abu Bakar menunjuk penggantinya Umar bin Khattab yang tujuannya adalah untuk mencegah supaya tidak terjadi perselisihan dan perpecahan di kalangan umat Islam dan kebijakan Abu Bakar tersebut ternyata dapat diterima kaum muslimin ketika itu. Pada masa khalifah Umar bin Khattab, kondisi politik dalam keadaan stabil, usaha perluasan wilayah Islam memperoleh hasil yang gemilang. Wilayah Islam pada masa ini meliputi Semenanjung Arabiah, Palestin, Syria, Irak, Persia, dan Mesir (Hanun Asrohah, 2001: 17).

Maka dengan meluasnya wilayah Islam mengakibatkan meluas pula kehidupan dalam segala bidang. Untuk memenuhi kebutuhan ini diperlukan sumber daya manusia yang memiliki keterampilan dan keahlian sehingga dalam hal tersebut dapat diperlukan pendidikan. Bahkan pada masa khalifah Umar bin Khattab, pendidikan sudah lebih meningkat di mana pada masa khalifah Umar di mana sahabat-sahabat yang sangat berpengaruh tidak diperbolehkan untuk keluar daerah kecuali atas izin dari khalifah dan dalam waktu terbatas. Jadi, kalau ada di antara umat Islam yang ingin belajar hadis maka harus pergi ke Madinah, ini berarti bahwa penyebaran ilmu pengetahuan para sahabat dan tempat pendidikan adalah berpusat di Madinah (Soekarno dan Ahmad Supadi, 1990: 51).

Dengan meluasnya wilayah Islam sampai keluar jazirah Arab, tampaknya khalifah memikirkan pendidikan Islam di daerah-daerah yang baru ditaklukkan itu. Untuk itu, Umar bin Khattab memerintahkan para panglima perangnya apabila mereka berhasil menguasai satu kota, hendaklah mereka mendirikan masjid sebagai tempat ibadah dan pendidikan. Berkaitan dengan masalah pendidikan itu, khalifah Umar merupakan seorang pendidik yang melakukan penyuluhan pendidikan di kota Madinah, beliau juga menerapkan pendidikan di masjid-masjid dan pasar-pasar (Muhammad Syadid, 2001: 37). Serta mengangkat dan menunjuk guru-guru untuk tiap-tiap daerah yang baru ditaklukan itu diangkat dan digaji untuk bertugas mengajarkan isi al-Qur'an dan ajaran Islam lainnya, seperti fikih kepada penduduk yang baru masuk Islam. Bahkan pada masa ini telah terjadi mobilitas penuntut ilmu dari daerah-daerah yang jauh dari Madinah, sebagai pusat agama Islam. Gairah menuntut ilmu agama Islam inilah yang kemudiannya mendorong lahirnya sejumlah pembidangan disiplin ilmu keagamaan lainnya.

Sementara pendidikan pada masa khalifah Usman bin Affan sebagai khalifah yang diangkat menggantikan khalifah Umar bin Khattab menjelang kewafatan beliau. Usman diangkat menjadi khalifah hasil pemilihan panitia enam ${ }^{3}$ yang ditunjuk sendiri oleh khalifah Umar bin Khattab. Pelaksanaan pendidikan pada masa khalifah Usman bin Affan tidak jauh berbeda dengan masa sebelumnya. Pendidikan di masa ini hanya melanjutkan apa yang telah ada sebelumnya, namun hanya sedikit terjadi perubahan yang mewarnai pendidikan Islam. Polanya juga mengikut di mana para sahabat yang berpengaruh dan dekat dengan Rasulullah tidak diperbolehkan meninggalkan Madinah di masa khalifah Umar, di masa Usman sedikit diberikan kelonggaran untuk keluar dan

\footnotetext{
${ }^{3}$ Panitia yang enam adalah termasuk Usman bin Affan sendiri, Ali bin Abi Thalib, Thalhah bin Ubaidillah, Zubair bin Awwam, Sa'ad bin Abi Waqash, dan Abdurrahman bin 'Auf.
} 
menetap di daerah-daerah yang mereka sukai dan biasanya diserahkan kepada rakyat dan sahabat yang tidak hanya terfokus proses pengajaran dan pembelajaran di Madinah saja tetapi sudah diperluaskan ke daerah-daerah. Hal ini merupakan kebijakan yang sangat besar pengaruhnya bagi pelaksanaan pendidikan di wilayah-wilayah perluasan Islam lainnya.

Sedangkan pada masa khalifah Ali bin Abi Thalib sebagai khalifah yang keempat setelah Usman bin Affan. Pada masa pemerintahannya sudah digoncang dengan peperangan Aisyah (istri Nabi) beserta Thalhah bin Ubaidillah dan Abdullah bin Zubair karena kesalah pahaman dalam menyikapi pembunuhan terhadap Usman, peperangan ini dikenal dengan perang Jamal (unta) karena Aisyah menggunakan kendaraan unta. Setelah berhasil mengatasi pemberontakan Aisyah, muncul pula pemberontakan lain sehingga masa kekuasaan khalifah Ali bin Abi Thalib tidak pernah mendapatkan ketenangan dan kedamaian (Hanun Asrohah, 2001: 21). Muawiyah pula sebagai gubernur di Damaskus memberontak untuk menggulingkan kekuasaannya, dan peperangan ini disebut dengan peperangan Shiffin karena terjadi di Shiffin.

Dengan terjadinya kekacauan dan pemberontakan sehingga di masa Ali berkuasa pemerintahannya tidak stabil maka pendidikan kurang mendapat perhatian, hal ini disebabkan pemerintahan Ali selalu dilanda konflik yang berujung kepada kekacauan dan perang saudara. Dengan kericuhan politik sangat berpengaruh kepada kegiatan pendidikan yang tidak mendapat perhatian bahkan mendapat hambatan dan gangguan dari segala sisinya, bahkan pada masa ini Ali tidak sempat lagi memikirkan masalah pendidikan sebab keseluruhan perhatiannya ditumpukan pada masalah keamanan dan kedamaian bagi masyarakat Islam. Dengan demikian, pola pendidikan secara keseluruhan pada masa khulafau al-Rasyidin tidak jauh berbeda dengan masa Nabi yang menekankan kepada pengajaran baca tulis dan ajaran-ajaran Islam yang bersumber kepada al-Qur'an dan al-Hadis.

\section{Lanjutan Pendidikan Islam pada Periode Dinasti Umayyah}

Berakhirnya kekuasaan khalifah Ali bin Abi Thalib, maka lahirlah kekuasaan dinasti bani Umayyah. Pada periode kepemimpinan Khulafau al-Rasyidin sebelumnya, pola kepemimpinan mereka masih mengikuti keteladanan Nabi, para khalifah dipilih melalui proses musyawarah, ketika menghadapi kesulitan-kesulitan mereka mengambil kebijakan langsung melalui musyawarah dengan para pembesar lainnya. Akan tetapi hal ini jauh berbeda dengan masa sesudahnya atau masa dinasti-dinasti yang berkembang sesudahnya di mulai pada masa dinasti bani Umayyah yang sejak awal telah menjadi Gubernur di Damaskus. Muawiyah dikenal dengan gaya kepemimpinannya yang kuat, ia menjadi landasan kepemimpinan, politikus, serta profesional dalam mengatur administrasi pemerintahan yang hal ini sudah terlihat dari peranan pernah dimainkan semenjak zaman Rasulullah SAW.

Adapun bentuk pemerintahannya pada awalnya adalah bersifat demokrasi lalu berubah menjadi kerajaan dengan kekuasaan bersifat feodal atau kekuasaan turun temurun. Pusat pemerintahannya bertempat di kota Damaskus hal ini dimaksudkan agar lebih mudah dalam memerintah karena Muawiyah sudah begitu lama memegang kekuasaan di wilayah tersebut serta ekspansi teritorial sudah begitu luas. Selain itu, untuk mempertahankan kekuasaannya khalifah berani bersikap otoriter, adanya unsur kekerasan, diplomasi yang diiringi dengan tipu daya serta hilangnya musyawarah dalam pemilihan khalifah.

Dinasti Umayyah berkuasa kurang lebih selama 91 tahun (41-132 H atau 661$750 \mathrm{M}$ ), dengan 14 orang khalifah yang dimulai Umayyah ibn Abu Sufyan dan diakhiri 
oleh Marwan ibn Muhammad yang sebenarnya pemerintahan dari keturunan Abu Sufyan hanya sampai pada Muawiyah II dan kemudian dilanjutkan oleh keturunan Abul 'Ash. Selama dinasti ini berkuasa berbagai kemajuan telah diperoleh dan reformasi cukup banyak terjadi. Dalam bidang administrasi misalnya telah terbentuk berbagai lembaga administrasi pemerintah yang mendukung tampuk pimpinan dinasti Umayyah. Banyak terjadi kebijaksanaan dilakukan pada masa ini. Terkait pada bidang pengembangan dan kemajuan pendidikan Islam. Perkembangan ilmu tidak hanya dalam bidang agama semata melainkan juga dalam aspek tekhnologi. Sementara sistem pendidikan masih sama ketika masa Rasulullah dan Khulafau al-Rasyidin iaitu kuttab yang pelaksanaannya berpusat pada masjid, istana, dan rumah guru.

Kebijakan pada periode ini di antaranya menyentuh segala sisi yakni pemisahan kekuasaan, pembagian wilayah, penyusunan bidang administrasi pemerintahan, organisasi keuangan berbentuk Baitu al-Mal, organisasi ketentaraan, organisasi kehakiman, bidang sosial, budaya, seni, sastera, seni rupa dan bidang arsitektur. Selain perhatian tersebut, pemerintahan dinasti ini juga menaruh perhatian dalam bidang pendidikan. Memberikan dorongan kuat terhadap dunia pendidikan dengan penyediaan sarana dan prasarana. Hal ini dilakukan agar para ilmuan, seniman, ulama dan sebagainya mahu melakukan pengembangan bidang ilmu yang dikuasainya serta mampu melakukan kaderisasi ilmu. Di antara ilmu pengetahuan yang berkembang pada masa ini adalah ilmu agama, sejarah, geografi, bahasa, dan filsafat serta kedokteran.

Pada prinsipnya pola pendidikan periode dinasti Umayyah ini telah berkembang jika dilihat dari aspek pengajaran dan pembelajarannya seperti pendidikan istana, nasehat pembesar kepada muaddib, badiah, perpustakaan, dan bamaristan (rumah sakit). Selain itu, meskipun bentuknya menggunakan sistem masih hampir sama seperti yang diterapkan pada masa Nabi dan Khulafau al-Rasyidin. Pada masa ini peradaban Islam sudah bersifat internasional dengan meliputi tiga benua iaitu sebagian Eropa, sebagian Afrika dan sebagian besar Asia yang kesemuanya itu dipersatukan dengan bahasa Arab sebagai bahasa resmi negara.

\section{Pengembangan Pendidikan Islam Periode Abbasiyah}

Sistem pemerintahan ke khalifah atau pemerintahan bani Abbasiyah meniru cara Umayyah bukan mencontoh khulafau al-Rasyidin yang berdasarkan pemilihan khalifah dengan musyawarah dari rakyat. Dan ada satu hal yang baru lagi bagi khalifah Abbasiyah ialah pemakaian gelar al-Mansyur. Dalam masa pemerintahannya terjadi pembunuhan terhadap orang-orang kuat berjasa dalam merebut kekuasaan dari tangan bani Umayyah karena khalifah itu tidak ingin ada tandingannya sehingga melapangkan dan memuluskan jalan segala keinginannya. Dalam masa pemerintahan al-Mansyur, ibu kota Bani Abbas dipindahkan ke kota Baghdad. Beliau memerintah selama 22 tahun dan wafat tahun $158 \mathrm{H}$, sebelum wafatnya beliau telah mewasiatkan kepada anaknya alMahdi untuk menggantikannya dengan menomorduakan Isa ibn Musa yang pernah ditetapkan oleh as-Saffah untuk memegang pemerintahan setelah al-Mansyur.

Dalam masa pemerintahan al-Mahdi terjadi perubahan dari sifat keras yang diterapkan oleh ayahnya ke sifat moderat dan murah hati. Beliau mengembalikan harta kekayaan yang disita oleh ayahnya kepada pemiliknya, serta membebaskan para tawanan politik dari kelompok Syi'ah serta memerangi kaum kafir yang menyimpang dari ajaran Islam. Selain itu, sistem politik Abbasiyah yang dijalankan adalah meliputi ketetapan para khalifah tetap dari keturunan Arab murni, kota Baghdad dijadikan sebagai ibu kota negara yang menjadi pusat segala kegiatan politik, ilmu pengetahuan yang dipandang sebagai sesuatu sangat penting, kebebasan berfikir sebagai HAM diakui 
penuh, dan para menteri turunan Persia diberi hak penuh dalam menjalankan pemerintahan.

Sementara sistem pendidikan Islam yang diterapkan dalam pemerintahan Abbasiyah terus berkembang sesuai dengan ketentuan-ketentuan berlaku mengikut perkembangan masa yang berlaku termasuk penerapan ilmu pengetahuan dan teknologi serta penterjemahan diperhebat dari berbagai bahasa asing ke dalam bahasa Arab atau sebaliknya. Selain itu, kekuasaan yang tertinggi diletakkan pada ulama sehingga pemerintahannya merupakan sistem teokrasi. Khalifah bukan saja berkuasa di bidang pemerintahan duniawi tapi juga berhak memimpin agama berdasarkan pemerintahan agamanya. Khalifah Abbasiyah juga memakai gelaran imam untuk menunjukkan aspek keagamaannya.

Setelah dinasti Abbasiyah lama berkibar akhirnya juga memasuki masa kemundurannya yang disebabkan dua faktor utama. Pertama, faktor internal yang berupa adanya konflik internal keluarga istana, tampilnya dominasi militer, permasalahan keuangan, berdirinya dinasti-dinasti kecil, luasnya wilayah kekuasaannya, dan fanatisme keagamaan. Kedua, faktor eksternal iaitu dengan adanya perang salib dan serangan tentra Mongol. Dengan keruntuhan tersebut, maka pendidikan Islam juga mengalami kemunduran, di antara kemunduran tersebut adalah dengan berkembangnya ajaran sufi akibat kemunduran Islam, terjadinya penyempitan kurikulum pendidikan Islam yang berdampak kepada pengembangan intelektual, tidak berkembangnya ilmu pengetahuan intelektual disebabkan paradigma di tengah kaum Muslimin di mana waktu itu pintu ijtihad telah tertutup dan lain sebagainya.

\section{Pengukuhan Pendidikan Islam Era Keemasan Dinasti Usmaniah}

Pengaruh pemerintahan Islam telah berakhir melalui dinasti Abbasyiah, tetapi masih muncul kerajaan-kerajaan kecil di beberapa daerah dan wilayah. Selanjutnya munculnya kerajaan Turki Usmani (dinasti Usmaniah) memiliki peranan yang sangat penting, baik dalam pengembangan kebudayaan maupun dalam perluasan wilayah kekuasaan Islam. Perluasan wilayah tersebut meliputi tiga benua (Asia, Afrika, dan Eropa) dan dua lautan (laut Tengah dan laut Merah). Kondisi demikian memberikan gambaran bahwa dinasti ini telah memiliki sistem politik pemerintahan yang teratur, kekuatan militer yang tangguh dalam rangka menjaga keamanan teritorial, dan ekonomi yang mapan. Maka pada era pemerintahan dinasti Usmaniah inilah di mana kebudayaan dan peradaban Islam berkembang cukup pesat, terutama nilai-nilai arsitektur maju dan bernilai tinggi. Akan tetapi jika kebudayaan dan peradaban Islam dimaknai bahwa pada era ini pertumbuhannya kurang berkembang subur. Hal ini dapat dilihat dari tidak diperolehnya data yang mengatakan bahwa pada era ini muncul para imuwan dan ulama besar, sebagaimana pada masa pemerintahan dinasti-dinasti Islam sebelumnya.

Dinasti Usmaniah sangat intens pada pembangunan masjid di setiap wilayah kekuasaannya. Bahkan pada perkembangannya, setiap panguasa berupaya untuk senantiasa membangun masjid sebagai bukti kekuasaannya. Hal ini membuktikan bahwa eksistensi masjid merupakan simbol kejayaan peradaban Islam. Perkembangan wilayah kekuasaan Islam telah menyebabkan terjadinya persentuhan kebudayaan Islam dengan kebudayaan wilayah yang dikuasai seperti Romawi, Byzantium, Persia, Andalusia, dan daerah lainnya yang telah memiliki nilai tinggi. Di antara persentuhan tersebut adalah pada seni arsitektur yang membuat seni ini sebagai salah satu bukti ketinggian kebudayaan Islam waktu itu. Ketinggian seni arsitektur Islam secara mudah dapat dilihat dari bangunan-bangunan yang ada pada wilayah kekuasaan Islam, khususnya bangunan masjidnya yang mengalami perkembangan cukup pesat 
(Muhammad al-Khatib, 1982: 13). Bentuk arsitektur Islam memiliki nilai universalitas yang tinggi, hal ini disebabkan karena dalam perkembangannya seni ini dibangun dengan dasar religiusitas tanpa meninggalkan nilai seni lokal di mana seni arsitektur tersebut dikembangkan.

Kebijakan pada awal perkembangan arsitektur dinasti Usmaniah dapat dilihat dari kebijakan penguasa dinasti ini ketika menerapkan sistem ibu kota pemerintahannya. Sebab bagaimana juga kebijakan ini merupakan subsistem yang terkait erat dengan strategi pembangunan negara dan perkembangan seni arsitektur pada era selanjutnya. Kemudian di tangan dinasti Usmaniah inilah kebudayaan yang ditinggalkan bangsa Romawi, Byzantium, dan Persia dapat terakomodasi dengan baik. Hal ini dapat dilihat dari kebijakan pemerintahan waktu itu yang inklusif terhadap kebudayaan lokal tanpa meninggalkan warna khas Islam. Umpamanya di bidang etika dan tatakrama mereka mengadopsi dari kebudayaan Persia, organisasi militer dari kebudayaan Byzantium, arsitektur bangunan dan tata kota dari kebudayaan Romawi dan Byzantium, sedangkan prinsip-prinsip ekonomi, sosial kemasyarakatan dan ilmu pengetahuan dari kebudayaan bangsa Arab (Ira M. Lapidus, $\quad$ 1999: 335).

\section{Perluasan Pendidikan Islam ke Eropa}

Membicarakan kontek sejarah pendidikan dan peradaban Islam ke Eropa sangat menarik untuk dicermati dan dikaji, sebab membicarakan hal ini merupakan perjalanan panjang yang terus meluas, mendalam, mendasar, serta jatuh bangunnya umat Islam selama kurun lebih 7,5 abad ini di daratan bumi Eropa. Selain itu, sebab ekspansi Islam ke Spanyol merupakan ekspansi wilayah yang paling gemilang dalam catatan sejarah kemiliteran dan peradaban yang dimiliki umat Islam ketika itu (Philip K. Hitti, 1970: 493). Di bidang kemiliteran terbukti dengan kemampuan umat Islam terutama masa dinasti Umayyah yang telah menguasai Spanyol dari kekuatan Visigotic yang terkenal cukup kuat ketika itu. ${ }^{4}$

Sedangkan di bidang peradaban, Islam Spanyol telah membawa peranan penting dalam konteks sejarah peradaban dan kebudayaan Islam. Kepesatan perkembangan peradaban dan kebudayaan yang dikembangkan Islam Spanyol telah membawa Span yol sebagai pusat kebudayaan dan peradaban Islam di Barat, sebagaimana halnya dengan Baghdad yang menjadi pusat kebudayaan dan peradaban Islam di Timur. Kehadiran dan perkembangan kebudayaan serta peradaban di Spanyol ini bukan saja telah memberikan warna dan ketinggian peradaban dunia Islam, bahkan kehadirannya juga telah memainkan peranannya dalam membidani dan memberikan konstribusi yang sangat besar terhadap kebangkitan bangsa Eropa pada abad pertengahan (Mehdi Nakosteen, 1996: 12).

Sementara kegemilangan pendidikan yang diperkenalkan dunia Islam di Spanyol dari abad ke-VI sampai abad ke-X telah menyadarkan Barat akan ketertinggalannya selama ini. Untuk itu, mulai abad ke-XI Eropa mulai melakukan upaya pentransferan ilmu pengetahuan yang bekembang di dunia Islam ke dunia Barat

\footnotetext{
${ }^{4}$ Secara kronologis kondisi Spanyol pra-Islam telah dikuasai oleh beberapa suku bangsa. Pertama, abad ke-2 M Spanyol merupakan wilayah taklukan bangsa Romawi. Pada masa itu berkembang agama Kristen, kebudayaan, undang-undang, dan seni Romawi. Kedua, pada masa Romawi memerintah, di Spanyol berdatangan imigran Yahudi yang lama kelamaan menjadi penduduk mayoritas. Ketiga, sekitar tahun $406 \mathrm{M}$ berdatangan pula bangsa Vandal dan berkuasa di sana sehingga tahun 507 M. Keempat, tahun 507 M, Spanyol berhasil dikuasai oleh bangsa Visigotic yang kemudian mendirikan kerajaan Gothic (Abdul Hamid al-Ibadi, 1964: 32). Adapun penyebab kelemahan Visigotic yang mempercepat keruntuhannya di tangan kaum Muslimin adalah terjadinya Chaos politik di kalangan istana Raja Roderik, hal inilah yang menyebabkan terjadinya keretakan intern mereka seperti keberpihakan beberapa pejabat pada ekspansi kaum Muslimin (Mahmudunnasir, 1981: 494).
} 
melalui Spanyol, Sicilia, dan Perang Salib (Harun Nasution, 1979: 74). Dengan melihat data sejarah tersebut, maka sangat beralasan untuk mengatakan bahwa jika seandainya Islam tidak diseberangkan dari Benua Afrika bagian utara ke Semananjung Iberia (Andalusia-Spanyol), mungkin Eropa tidak akan mengalami kemajuan peradabannya sepesat dan secepat yang kita saksikan dewasa ini.

Oleh karena itu, dengan kedatangan Islam ke Spanyol telah membawa perubahan sangat besar, terutama di bidang sosial dan ilmu pengetahuan serta kebudayaan. Perkembangan peradaban Islam Spanyol terbentuk bukan hanya karena sentuhan dari tradisi Arab-Islam, akan tetapi lebih dari itu adanya persentuhan peradaban yang dibawa oleh Arab-Islam dengan kebudayaan masyarakat multibudaya inilah yang akhirnya terikat menjadi satu dan membentuk kebudayaan Islam yang tinggi waktu itu. Semua ini juga tidak terlepas dari kepiawaian dan dukungan dari penguasa dalam memajukan ilmu pengetahuan dan tingginya motivasi umat Islam dalam mengembangkan ilmu pengetahuan dan kebudayaan tersebut.

Sehingga dalam waktu singkat Spanyol berubah menjadi pusat pengembangan ilmu pengetahuan Islam di belahan Barat. ${ }^{5}$ Kondisi ini membuat Eropa harus berkiblat pada semua aspek kebudayaan manusia terhadap Spanyol dan Islam. Bahkan jika masyarakat Eropa memerlukan tabib, arsitek, guru, atau penjahit, maka Cordova sebagai ibu kota Spanyol ketika itu adalah tempatnya untuk memenuhi segala kebutuhan tersebut (Philip K. Hitti, 1970: 166). Tingginya ghirah umat Islam dalam mengembangkan ilmu pengetahuan dan kebudayaan, merupakan modal yang terbesar. Hal ini dapat dibuktikan meskipun pemerintahan dinasti Umayyah telah hancur (1031 M), dan terpecahnya politik pemerintahan Muluk al-Thawaif, namun pada waktu bersamaan terjadi kecemerlangan kultural. Pada masa Bani Akhmar misalnnya, telah menyulap kota Granada menjadi sebuah kota ilmu pengetahuan dan peradaban selama dua setengah abad lamanya (1230-1492 M), sehingga menjadi daya tarik perhatian cendekiawan dan sastrawan dari segenap penjuru dunia (C.E. Boswort, 1993: 41). ${ }^{6}$

Untuk menunjang pendidikannya, Islam di Spanyol telah memberlakukan kurikulum universal dan konprehensif. Artinya dalam pembelajaran mereka menawarkan materi pendidikan agama dan umum secara integral pada setiap tingkatan pendidikannya, khususnya pendidikan tinggi. Indikasi dari kedalaman dan keluasan kurikulum Spanyol waktu itu boleh jadi ditentukan konsekuensi-konsekuensi praktikal yang bermanfaat bagi kehidupan manusia, sehingga pola kurikulum yang diterapkan tidak bersifat fleksibel dan adaptik. Untuk pendidikan kejuruan, kurikulumnya boleh memberikan penekanan khusus pada spesialisasi yang ditawarkan. Pengembangan kebijaksanaan ini diberikan hak kepada lembaga atau penguasa di mana pendidikan itu dilaksanakan. $^{7}$

Sedangkan metode yang biasa diterapkan dapat dibagi kepada dua macam. Pertama, metode bagi pendidikan formal. Pada pendidikan ini guru (dosen) duduk di atas podium lalu ia memberikan materi pelajaran khususnya pendidikan tinggi atau

\footnotetext{
${ }^{5}$ Pada kurun waktu itu, selain Baghdad di Timur, pusat kebudayaan dan ilmu pengetahuan Spanyol dan Islam telah meliputi: Cordova Seville, Toledo, dan Granada (Harild E. Mitzel, 1982: 795). Perkembangan ini tidak terlepas dari sikap toleran dan persahabatan yang ditawarkan Islam pada penduduk pribumi, tanpa merusak dan memaksakan kebudayaan mereka, akan tetapi melakukan asimilasi dengan nilai-nilai Islam (Mehdi Nakosteen, 1996: 5).

${ }^{6}$ Pada masa ini sebagaimana yang dikutip Dozy, hampir semua masyarakat Spanyol dan Islam telah dapat membaca dan menulis. Padahal sebelumnya, masyarakat Spanyol buta huruf dan picik. Pengetahuan masyarakat pra-Islam hanya para pendeta saja (Philip K. Hitti, 1970: 169).

${ }^{7}$ Secara umum, bidang studi yang ditawarkan dalam kurikulum pendidikan Islam di Spanyol antara lain adalah: Pendidikan umum, matematika, sains, ilmu kedokteran, filsafat, keusasteraan, sejarah, geografi, hukum, politik, dan sebagainya. Sedangkan pendidikan agama meliputi bidang studi: al-Qur'an, al-Hadis, fikih, ushul fikih, teologi, dan lain sebagainya (Mehdi Nakosteen, 1996: 74).
} 
dengan membacakan manuskrip-manuskrip. Setelah itu, guru menerangkan secara jelas, kemudian materi didiskusikan bersama. Para pelajar diberikan kebebasan untuk bertanya dan mengeluarkan pendapat, bahkan diperkenankan untuk berbeda pendapat dengan guru asalkan dapat mengajukan bukti-bukti yang mendukung kebenaran pendapatnya tersebut. Kedua, metode pendidikan bagi bentuk nonformal, baik di istana maupun di luar istana. Model pendidikan ini menggunakan metode halaqah. Posisi guru (dosen) berada di antara para pelajarnya. Guru mendiktekan sejumlah buku, dan kemudian menjelaskannya secara terperinci. Metode pengajaran seperti ini merupakan pola pengajaran dan pembelajaran yang telah membumi di Spanyol ketika itu.

\section{Pengaruh Madrasah Nizhamiyah terhadap Perkembangan Pendidikan Islam}

Sejarah pendidikan Islam mencapai puncak kejayaannya pada masa Umayyah dan Abbasiyah, ini tidak terlepas dari keberhasilan para ahli dan pakar pendidikan masa itu. Bukti dari keberhasilan tersebut telah dapat dirasakan oleh umat Islam dalam berbagai cabang dan bidang yang juga merupakan cikal bakal munculnya pencerahan di dunia Barat. Selain itu, pelaksanaan pendidikan Islam pada masa itu mengalami prioritas, dimulai dari tingkat sederhana hingga tingkat tinggi, baik yang dikelola perorangan sampai yang dikelola oleh khalifah (pemerintah). Pengelolaan ini adalah seperti pendidikan Islam yang dilaksanakan di rumah-rumah, kuttab-kuttab, di masjid, serta madrasah. Dari sinilah mulanya para pelajar dan sarjana Muslim bahkan nonmuslim menuntut berbagai disiplin ilmu yang mereka minati.

Ketika Abbasiyah mengalami kemunduran di Baghdad yang menjadi kerajaankerajaan kecil dan berkuasanya orang-orang Turki, masalah pendidikan tetap menjadi perhatian besar para khalifah dan orang-orang kaya sehingga pendidikan berhasil mencetak para pelajar dan sarjana sesuai dengan kepakaran yang diharapkan. Di tiap negara Islam pemerintah membutuhkan pegawai-pegawai resmi (wazir) dalam menjalankan pemerintahan negara, untuk mendukung keinginan tersebut sehingga muncul sistem perskolahan (madrasah). Di samping itu, keberhasilan pendidikan selalu mendapat perhatian dari pemerintah dan orang-orang kaya, seperti menyediakan sarana dan prasarana pendidikan terutama perpustakaan, gedung madrasah, dan membantu para siswa untuk biaya pendidikan sehingga mereka dapat belajar dengan gratis. Pada masa khalifah Abbasiyah Malik Syah, wazir Nizham al-Mulk dari bani Saljuk misalnya, beliau membangun Madrasah Nizhamiyah yang mana madrasah inilah yang nantinya menjadi perguruan Tinggi Islam berkembang dan terbesar pada zamannya.

Kewujudan Madrasah Nizhamiyah sebagai sebuah lembaga pendidikan yang didirikan pada tahun 457-459 H/1065-1067 M (abad ke-IV) oleh Nizham Mulk dari Dinasti Saljuk. Menurut sejarahnya bahwa madrasah ini yang pertama kali muncul dalam sejarah pendidikan Islam berbentuk lembaga pendidikan dasar sampai perguruan tinggi yang dikelola oleh kerajaan atau pemerintah. Madrasah ini didirikan gedunggedung ilmiah untuk ahli fikih, membangun madrasah-madrasah untuk para ulama dan asrama untuk orang beribadah serta fakir miskin. Pelajar yang tinggal di asrama diberi belanja secukupnya dari uang negara dengan jumlah yang tidak sedikit dari Nizham alMulk. Akibatnya, Nizham al-Mulk mendapat teguran dari Malik Syah karena diadukan orang bahwa uang yang dibelanjakan untuk kepentikan pendidikan dan pengajaran tersebut merupakan usaha Nizham al-Mulk untuk menaklukkan kota Qustaniah (Constantinopel) (Mahmud Yunus, 1990: 70). Tindakan Nizham al-Mulk ini akhirnya dapat diterima oleh Malik Syah setelah dijelaskan alasan yang logis dan bahkan dapat menyadarkan khalifah. Begitu besarnya perhatian Nizham al-Mulk terhadap pendidikan dan pengajaran sebagaimana yang dinyatakan oleh Ahmad Syalabi (1973: 108): 
"Tidak satu pun negeri yang didapatkan tiada mendirikan madrasah oleh Nizham al-Mulk, sehingga pulau yang terpencil di sudut dunia yang jarang didatangi manusia juga didirikan madrasah yang besar lagi bagus. Ditemukannya orang terkenal berpengetahuan luas dan mendalam disuruh mengajar dan memberi sekolah itu wakaf dilengkapi dengan perpustakaan."

Madrasah Nizham al-Mulk bernama Nizhamiyah dan termasyhur di seluruh dunia. Di antara madrasah tersebut yang terkenal dan terpenting adalah Nizhamiyah di Baghdad (selain madrasah di Balkh, Naisabur, Jarat, Ashfahan, Basrah, Marw, dan lainlainnya). Madrasah-madrasah Nizhamiyah itu dapat disamakan dengan fakultasfakultas atau perguruan tinggi masa sekarang, mengingat gurunya adalah ulama besar yang masyhur. Sementara tujuan Nizham al-Mulk mendirikan madrasah-madrasah tersebut adalah untuk memperkuat pemerintah Turki Saljuk dan untuk menyiarkan mazhab keagamaan pemerintahan. Karena sultan-sultan Turki adalah dari golongan ahli sunah, sedangkan pemerintahan Buwaihiyah yang sebelumnya adalah kaum Syi'ah (Mahmud Yunus, 1990: 172), oleh sebab itu Madrasah Nizhamiyah adalah diasaskan untuk menyokong sultan dan menyiarkan mazhab ahli sunah ke seluruh penduduk dan masyarakatnya.

Untuk memberantas mazhab-mazhab yang ditanamkan oleh golongan Syi'ah kepada rakyat yang dianggap batil, maka Nizham al-Mulk berupaya semaksimal mungkin mendirikan Madrasah Nizhamiyah untuk menanamkan mazhab ahli sunah yang dianggap lebih benar, karena kepercayaan ahli sunah adalah berdasarkan pelajaran-pelajaran agama yang benar (Ahmad Syalabi, 1973: 109) yang lebih memprioritaskan al-Qur'an dan as-Sunah dibandingkan dengan $r a$ 'yi. Oleh karena itu, penanaman kepercayaan, menarik perhatian pelajar atau mahasiswa dalam belajar, dan sikap sangat setia kepada khalifah dapat mengukuhkan mazhab ahlu sunnah dan melemahkan pengaruh kedudukan Syi'ah, karena perhatian ahlu sunnah sangat besar terhadap ilmu fikih yang terdapat dalam empat mazhab fikih (Asma Hasan Fahmi, 1979: 41).

Menurut sejarah Islam, Nizham al-Mulk adalah orang yang mula-mula mendirikan madrasah, sedangkan Darul Hikmah yang ada pada waktu itu hanya dijadikan sebagai gedung perpustakaan saja, maka dapat difahami bahwa Madrasah Nizhamiyah telah diorganisir oleh pemerintah, buktinya terlihat dari kurikulum, guruguru, struktur organisasinya, sarana dan prasarana, serta pembiayaan yang diurus oleh pemerintah (khalifah). Hal ini sekaligus merupakan kelebihan dan keunggulan Madrasah Nizhamiyah jika dibandingkan dengan lembaga pendidikan yang ada sebelumnya

Di samping itu, didapati bahwa rencana pengajaran di Madrasah Nizhamiyah tidak ditemui dengan tegas, menurut Mahmud Yunus rencana pengajarannya adalah ilmu-ilmu syariah saja dan tidak ada ilmu-ilmu hikmah (filsafat), ini terbukti sebagai berikut: (1) Para ahli sejarah tidak seorang pun yang mengatakan bahwa di antara mata pelajaran ada ilmu kedokteran, ilmu falak dan ilmu-ilmu pasti, mereka hanya menyebut mata pelajaran nahwu, ilmu kalam, dan fikih. (2) Guru-guru yang mengajar di Madrasah Nizhamiyah adalah ulama-ulama syariah sehingga madrasah tersebut merupakan madrasah syariah bukan madrasah filsafat. (3) Pendiri Madrasah Nizhamiyah itu bukanlah orang yang membela ilmu filsafat dan bukan pula orang-orang yang membantu pembebasan filsafat, dan (4) Zaman berdirinya Madrasah Nizhamiyah bukanlah zaman filsafat melainkan zaman menindas filsafat serta orang-orang filosuf. 
Kurikulum di Madrasah Nizhamiyah secara rinci menurut Mahmud Yunus (1990: 61) adalah; al-Qur'an (membaca, menghafal, dan menulis), sastera Arab, sejarah Nabi SAW, fikih, ushul fikih dengan menitik beratkan kepada mazhab Syafi'i dan sistem teologi Asy'ariyah. Berbeda dengan Hamid Hasan Bilgrami (1989: 48) yang berpendapat mengenai materi yang diberikan di Madrasah Nizhamiyah, beliau menyatakan bahwa pelajaran yang diberikan adalah mencakup ilmu bahasa tradisional, fikih, kajian-kajian Islam, ilmu hisab, faraid, penelitian tanah, sejarah sastera, kesehatan, cara memelihara binatang, bercocok tanam, serta beberapa segi dari sejarah kealaman. Demikianlah materi yang diberikan di Madrasah Nizhamiyah yang diarahkan untuk mengembangkan mazhab Sunni dan melemahkan mazhab Syi'ah serta Mu'tazilah. Oleh karena itu, materinya lebih berorientasi pada ilmu keagamaan melalui empat mazhab yakni Hanafi, Hambali, Maliki dan Syafi'i. Tetapi yang sangat menonjol adalah mazhab Syafi'i karena lulusannya dipersiapkan memang untuk itu dan untuk duduk di pemerintahan Saljuk yang bermazhab Sunni khususnya Syafi'i.

\section{Realisasi Pendidikan Islam di Nusantara}

Sejarah aplikasi pendidikan Islam di bumi Nusantara terutamanya wilayah Indonesia telah dimulai pada awal abad ke-XX Masehi sehingga dewasa ini merupakan perjalanan yang cukup panjang. Dimana perkembangannya sangat drastis terjadi pada masa orde lama, terus berkembang pada masa orde baru, dan masa reformasi sehingga kini. Pendidikan Islam ini aplikasinya banyak direalisasikan melalui sistem pengajaran dan pembelajaran pondok pesantren. Pondok pesantren sangat berperanan penting dalam membentuk karakter umat Islam dalam kehidupan masyarakatnya, karena pada prinsipnya dikatakan bahwa "Madrasah dan pesantren yang pada hakikatnya adalah satu sumber pendidikan dan pencerdasan rakyat jelata yang telah berurat dan berakar dalam masyarakat Indonesia pada umumnya, hendaknya mendapatkan perhatian dan bantuan nyata berupa tuntunan dan bantuan material dari pemerintah."

Tidak dapat dipungkiri bahwa lembaga pondok pesantren memainkan peranan penting dalam usaha memberikan pendidikan bagi bangsa Indonesia terutama pendidikan agama. Pesantren, dari awal mula berdirinya hingga saat ini masih terus dapat eksis dan berperan dalam upaya memberikan pendidikan yang bermutu. Kajian ini diarahkan untuk melihat dengan jelas perkembangan pendidikan Islam, dan pondok pesantren juga menjadi salah satu bagiannya sebagai dunia pendidikan secara tradisional dari awal mula kemunculannya hingga saat ini, juga berbagai macam dinamika yang terjadi mengiringi eksistensinya sebagai lembaga pendidikan dan pengayom dalam masyarakat Islam.

Sebetulnya secara umum, suatu pondok pesantren berawal dari adanya seorang kyai di suatu tempat, kemudian datang santri yang ingin belajar agama kepadanya. Setelah semakin hari semakin banyak santri yang datang, timbullah inisiatif untuk mendirikan pondok atau asrama di samping rumah kyai. Pada zaman dahulu kyai tidak merencanakan bagaimana membangun pondoknya itu, namun yang terpikir hanyalah bagaimana mengajarkan ilmu agama supaya dapat difahami dan dimengerti oleh santri. Kyai saat itu belum memberikan perhatian terhadap tempat-tempat didiami oleh para santri yang umumnya sangat kecil dan sederhana. Mereka menempati sebuah gedung atau rumah kecil yang mereka dirikan sendiri di sekitar rumah kyai. Semakin banyak jumlah santri, maka semakin bertambah pula gubug yang didirikan. Para santri selanjutnya mempopulerkan keberadaan pondok pesantren tersebut, sehingga menjadi terkenal kemana-mana, contohnya seperti pada pondok-pondok yang didirikan pada zaman Wali Songo. 
Sementara pondok pesantren di Indonesia memiliki peran yang sangat besar, baik bagi kemajuan Islam itu sendiri maupun bagi bangsa Indonesia secara keseluruhan. Berdasarkan catatan yang ada, kegiatan pendidikan agama di Nusantara telah dimulai sejak tahun 1596. Kegiatan agama inilah yang kemudian dikenal dengan nama pondok pesantren. Bahkan dalam catatan Howard M. Federspiel salah seorang pengkaji keIslaman di Indonesia, menjelang abad ke-12 pusat-pusat studi di Aceh (pesantren disebut dengan nama Dayah) dan Palembang (Sumatra), di Jawa Timur dan di Gowa (Sulawesi) telah menghasilkan tulisan-tulisan penting dan telah menarik santri untuk belajar. Sedangkan gambaran lain mengenai pondok pesantren adalah merupakan lembaga pendidikan tertua di negara ini. Dengan watak kemandirian dan corak pendidikannya yang khas, lembaga ini bertahan dan terus berkembang banyak tempat di Indonesia, bahkan dianggap sebagai wujud indegonius (wajah asli) pendidikan Nusantara.

Pada zaman penjajahan Belanda, dengan berbagai cara penjajah berusaha untuk mendiskreditkan pendidikan Islam yang dikelola oleh pribumi termasuk di dalamnya pesantren. Sebab pemerintah kolonial mendirikan lembaga pendidikan dengan sistem yang berlaku di Barat pada waktu itu, namun hal ini hanya diperuntukkan bagi golongan elit dari masyarakat setempat. Jadi ketika itu ada dua alternatif pendidikan bagi bangsa Indonesia. Sebagian besar sekolah kolonial diarahkan pada pembentukan masyarakat elit yang akan digunakan untuk mempertahankan supremasi politik dan ekonomi bagi pemerintah Belanda. Dengan didirikannya lembaga pendidikan atau sekolah yang diperuntukkan bagi sebagian bangsa Indonesia tersebut terutama bagi golongan priyayi dan pejabat oleh pemerintah kolonial, maka semenjak itulah terjadi persaingan antara lembaga pendidikan pesantren dengan lembaga pendidikan pemerintah.

Meskipun harus bersaing dengan sekolah-sekolah yang diselenggarakan pemerintah Belanda, pesantren terus berkembang jumlahnya. Persaingan yang terjadi bukan hanya dari segi ideologis dan cita-cita pendidikan saja, melainkan juga muncul dalam bentuk perlawanan politisi dan bahkan secara fisik. Hampir semua perlawanan fisik (peperangan) melawan pemerintah kolonial pada abad ke-19 bersumber atau paling tidak mendapatkan dukungan sepenuhnya dari pesantren, seperti perang paderi Diponegoro dan perang Banjar. Kenyataan tersebut menyebabkan pemerintah Belanda diakhir abad ke-19 mencurigai eksistensi pesantren, yang mereka anggap sebagai sumber perlawanan terhadap pemerintah Belanda. Oleh karena itu, pada tahun 1882 Belanda mendirikan Priesterreden (pengadilan agama) yang salah satu tugasnya adalah mengawasi pendidikan di pesantren. Kemudian dikeluarkan Ordonansi (undangundang) tahun 1905 mengenai pengawasan terhadap perguruan yang hanya mengajarkan agama (pesantren), dan guru-guru yang mengajar harus mendapatkan izin pemerintah setempat sebelum mereka mengajar.

Selanjutnya pesantren oleh beberapa anggota dari Wali Songo yang menggunakannya sebagai tempat mengajarkan ajaran-ajaran Islam kepada masyarakat Jawa. Sunan Bonang misalnya mendirikan pesantren di Tuban, Sunan Ampel mendirikan pesantren di Ampel Surabaya dan Sunan Giri mendirikan pesantren di Sidomukti yang kemudian tempat ini lebih dikenal dengan sebutan Giri Kedaton. Keberadaan Wali Songo yang juga pelopor berdirinya pesantren dalam perkembangan Islam di Jawa, sangatlah penting sehubungan dengan peranannya yang sangat dominan. Wali Songo melakukan satu proses yang tidak berujung, gradual dan berhasil menciptakan satu tatanan masyarakat santri yang saling damai dan tenang selalu 
berdampingan. Satu pendekatan yang sangat berkesesuaian dengan filsafat hidup masyarakat Jawa yang menekankan kestabilitas, keamanan, dan keharmonian.

Seiring dengan perkembangan sekolah-sekolah Barat modern yang mulai menjamah sebagian masyarakat Indonesia, pesantren pun tampaknya mengalami perkembangan yang bersifat kualitatif, meskipun ruang geraknya senantiasa diawasi dan dibatasi. Ide-ide pembaharuan dalam Islam, termasuk pembaharuan dalam pendidikan mulai masuk ke Indonesia, dan mulai merambah masuk ke dunia pesantren serta dunia pendidikan Islam lainnya. Akhirnya pembaharuan ini menyebabkan sistem modern klasikal mulai masuk ke pesantren, yang sebelumnya masih belum dikenal. Metode halaqah (sorogan) berubah menjadi sistem klasikal, dengan mulai menggunakan kursi, meja, dan mengajarkan pelajaran umum. Sementara itu beberapa pesantren mulai memperkenalkan sistem madrasah sebagaimana yang telah diterapkan pada sekolah-sekolah pada umumnya.

Dalam sejarahnya mengenai peran pesantren, dimana sejak masa kebangkitan nasional sampai dengan perjuangan mempertahankan kemerdekaan RI, pesantren senantiasa tampil dan telah mampu berpartisipasi secara aktif. Oleh karena itulah setelah kemerdekaan pesantren masih mendapatkan tempat dihati masyarakat. Ki Hajar Dewantara saja selaku tokoh pendidikan nasional dan Menteri Pendididkan Pengajaran Indonesia yang pertama, telah menyatakan bahwa pondok pesantren merupakan dasar pendidikan nasional, karena sesuai dan selaras dengan jiwa dan kepribadian bangsa Indonesia.

Begitupula halnya dengan pemerintah RI, mengakui bahwa pesantren dan madrasah merupakan dasar pendidikan dan sumber pendidikan nasional, dan oleh karena itu harus dikembangkan, diberi bimbingan, dan bantuan. Sejak awal kehadiran pesantren dengan sifatnya yang lentur (flexible) ternyata mampu menyesuaikan diri dengan masyarakat serta memenuhi tuntutan masyarakat. Begitu juga pada era kemerdekaan dan pembangunan sekarang, pesantren telah mampu menampilkan dirinya aktif mengisi kemerdekaan dan pembangunan, terutama dalam rangka pengembangan sumber daya manusia yang berkualitas. Dan ad berbagai inovasi telah dilakukan untuk pengembangan pesantren baik oleh masyarakat maupun pemerintah.

Masuknya pengetahuan umum dan keterampilan ke dalam dunia pesantren adalah sebagai upaya memberikan bekal tambahan agar para santri bila telah menyelesaikan pendidikannya dapat hidup layak dalam masyarakat mereka. Sehinga pada dewasa ini pondok pesantren mempunyai kecenderungan-kecenderungan baru dalam rangka merenovasi terhadap sistem yang selama ini dipergunakan, diantaranya adalah mulai akrab dengan metodologi ilmiah modern, dan semakin berorientasi pada pendidikan dan fungsional, artinya terbuka atas perkembangan di luar dirinya. Juga diversifikasi program dan kegiatannya juga semakin terbuka dan ketergantungannya pun absolute dengan kyai, dan sekaligus dapat membekali para santri mereka dengan berbagai pengetahuan di luar mata pelajaran agama maupun keterampilan yang diperlukan di lapangan kerja nanti, dan juga dapat berfungsi sebagai pusat pengembangan masyarakat.

Keberadaan pesantren-ulama-kyai-santri biasanya memiliki hubungan yang cukup erat dengan masyarakat sekelilingnya. Bahkan tradisi yang berlaku di dunia pesantren ini pun berlaku dalam dunia luar pesantren. Hal ini dapat terjadi dengan undangan dari masyarakat kepada kyai untuk menghadiri acara tertentu atau dari para alumni pesantren yang menyebar ke daerah-daerah untuk menyebarkan ilmu yang telah didapatkannya selama di pesantren. Seperti pada peringatan maulid Nabi, nuzul alQur'an, walimah al-ursy, pengajian dan lain sebagainya. Dari saling berkelindannya 
kyai-pesantren-santri ini tentunya memiliki pengaruh besar dalam masyarakat. Misalkan saja seorang santri yang baru masuk belajar di pesantren satu tahun saja, ketika pulang ke kampung halaman, di kampungnya akan diperlakukan layaknya sebagai seorang kyai oleh masyarakat di tempat mereka tinggal. Maka tidak jarang masyarakat karena kecintaan mereka terhadap pesantren banyak memberikan shadaqah, infaq, waqaf, dan amal jariyah lainnya dengan ikhlas untuk perkembangan sesebuah pondok pesantren.

Seiring dengan bergulirnya alur modernisasi, politik global mengalami rekonfigurasi di sepanjang lintas-batas kultural. Berbagai masyarakat dan negara yang memiliki kemiripan kebudayaan akan saling bergandengan. Sementara mereka yang berada di wilayah kebudayaan yang berbeda akan memisahkan diri dengan sendirinya. Berhadapan dengan globalisasi dan ancaman kuatnya benturan peradaban, maka tak mungkin pesantren masih bertahan dengan pola pembelajaran lama. Tuntutan masyarakat global adalah profesionalisme, penguasaan ilmu pengetahuan, teknologi serta etos kerja yang tinggi. Maka karena itulah watak profesionalitas dan penguasaan teknologi dan pengetahuan yang standar, diperlukan di pondok pesantren. Jika tidak tentunya pesantren harus siap-siap digilas oleh lajunya perkembangan zaman, atau ditinggalkan orang karena telah usang dan tak layak pakai.

Karena itu diharapkan pesantren harus semakin adaptif terhadap perkembangan kamajuan zaman. Atas dasar itu peluang pesantren sebagai lembaga pendidikan Islam yang akan menciptakan manusia seutuhnya akan semakin terbuka. Jika kita mengorelasikan benturan peradaban sebagaimana yang diramalkan Huntington, maka sesungguhnya konflik yang paling mudah menyebar dan sangat penting sekaligus berbahaya bukanlah konflik antar kelas sosial, antar golongan kyai dengan golongan miskin atau antara kelompok kekuatan ekonomi lainnya, akan tetapi konflik antara orang-orang yang memiliki etnis budaya yang berbeda. Pertikaian antar suku dan konflik-konflik antar etnis dalam peradaban akan senantiasa terjadi.

\section{SIMPULAN}

Sebagai kesimpulan, dapatlah direnungkan bahwa sejarah pendidikan Islam sudah melalui catatan panjang yang bisa dikatakan berawal dari proses pendidikan dalam rumah dan masjid. Namun tetap perlu diakui bahwa sejarahnya bermula sejak Nabi Adam AS sehingga ke Nabi Muhammad SAW melalui dakwah ketauhidan para Nabi dan Rasul-Nya. Kemudian asas pola pendidikan dikukuhkan lagi melalui fase Mekkah dan Madinah, berlanjut ke zaman para sahabat Khulafau al-Rasyidin, berterusan ke periode Dinasti Umayyah, berkembang pada periode Abbasiyah, berterusan ke periode Khalifah Usmaniah, menjalar sehingga ke Eropa, dan pada masa puncak keilmuan proses pendidikan berjalan terus menerus di masjid-masjid, dan abad ke-5 Hijriyah kurang lebih di era Imam Ghazali, muncul sebuah pola baru dalam dunia pendidikan Islam, bermula dengan Madrasah Nizhamiyah yang didirikan oleh Nizamul Mulk. Sejak Nizhamiyah, maka tren pendidikan Islam di peringkat tinggi mengarah kepada penggabungan empat madzhab dalam satu madrasah.

Tetapi perkembangan pendidikan Islam akhirnya memasuki juga masa kemundurannya ketika pengaruh pendidikan Barat mulai memasuki wilayah-wilayah Islam sehingga pengaruhnya masih dirasai sehingga sekarang. Walau demikian halnya, pendidikan Islam di Asia Tenggara masih tetap eksis melalui pondok-pondok pesantren yang dipandang sebagai suatu lembaga pendidikan Islam tertua di Nusantara terutamanya di Indonesia yang didirikan oleh para ulama dan kyai. Pondok pesantren didirikan dalam rangka usaha mendidik masyarakat untuk memahami dan melaksanakan ajaran Islam, dengan menekankan pentingnya moral keagamaan sebagai 
pedoman hidup. Pengertian tertua di sini, karena pesantren adalah lembaga yang telah lama hidup dan masih tetap wujud sehingga saat ini walaupun telah banyak berubah metode dan bentuknya, bahkan juga sudah ada yang berubah dari bentuk awal mulanya berdiri ke berbagai bidang. Bahkan pesantren juga telah menjadi bagian yang mendalam dari sistem kehidupan sebagian besar umat Islam di Nusantara dan turut mewarnai dinamika pendidikan anak-anak bangsanya.

Sementara perkembangan pendidikan dalam wilayah-wilayah Islam tersebut apabila dijalankan sesuai dengan penerapan pendidikan agama Islam yang telah ditetapkan, maka tidak menutup kemungkinan akan melahirkan pendidik-pendidik dan guru-guru hebat di masa akan datang yang dapat melahirkan peluang pengembangan sumber daya manusia di wilayah pendidikan tersebut dijalankan. Selain itu, potret pendidikan ini juga dapat mewarnai berbagai sisi kehidupan masyarakat disekitarnya terutama pengaruhnya dalam sistem politik, sosial, seni, budaya, kultur yang kemudiannya membentuk sistem pendidikan Islam yang terorganisir baik sehingga dapat memberikan sumbangan besar terhadap hidup dan kehidupan umat Islam untuk menuju perkembangan keilmuan dan keintelektualan mereka dari waktu ke waktu.

\section{DAFTAR PUSTAKA}

Abd Halim H. Mat Diah. 1989. Islam dan demokrasi pendidikan. Kuala Lumpur: ABIM.

Abdul Halim el-Muhammady. 1993. Pendidikan Islam era 2020; Satu penghayatan menyeluruh. Dalam Khailani Abdul Jalil \& Ishak Ali Shah (Ed.). Pendidikan Islam era 2020 tasawur dan strategi. Kajang: Bintang Jaya.

Abdul Hamid al-Ibadi. 1964. Al-Mujmal fi tarikh al-Andalus. Beirut: Dar al-Qalam.

Abdul Rahman an-Nawawi. T.th. Pendidikan Islam: Di rumah, di sekolah dan masyarakat. Tanpa tempat dan penerbit.

Abuddin Nata. 2001. Metodologi studi Islam. Jakarta: Pt. Raja Grafindo Persada.

Ahmad Salaby. 1973. Sejarah pendidikan Islam. Jakarta: Bulan Bintang.

Al-Markaz al-'Alami li al-ta'lim al-Islami, tausyah al-mu'tamar al-ta'limiyah alIslamiyah al-alamiyah al-arba'. 1983. Makka: Tanpa penerbit.

Al-Qur'an dan terjemahannya. 1986. Jakarta: Departemen Agama Republik Indonesia.

Al-Syeikh Muhammad Abduh. T.th. Muzakkirat al-imam Muhammad 'Abduh. Mesir: Dar al-Hilal.

Amin Haedari. 2007. Transformasi pesantren. Jakarta: Media Nusantara.

Asma Hasan Fahmi. 1979. Sejarah dan filsafat pendidikan Islam. Judul asli Mabadi' attarbiyat al-Ismiyah. Terj. Ibrahi Husein. Jakarta: Bulan Bintang.

Badri Yatim. 2001. Sejarah peradaban Islam. Jakarta: PT. Raja Grafindo Persada.

Burlian Somad. 1981. Beberapa persoalan dalam pendidikan Islam. Bandung: alMa'arif.

Fatah, H. Rohadi Abdul, Taufik, M. Tata, Bisri, Abdul Mukti. 2005. Rekontruksi pesantren masa depan. Jakarta Utara: PT. Listafariska Putra.

Ghazali Darussalam. 2001. Sumbangan sarjana dalam tamadun Islam. Kuala Lumpur: Utusan Publication and Distributors.

Girling, D.A., (ed.). 1978. Eryman's encyclopedia. London: JM. Dent \& Sons Ltd.

Haekal. 1972. Sejarah hidup Muhammad. Terj. Ali Audah. Jakarta: Tintamas.

Hamid Hasan Bilgrami. 1989. Konsep universitas Islam. Judul asli The concept of Islamic university. Terj. Macnum Husein. Yogyakarta: Tiara Wacana. 
Hanun Asrohah. 2001. Sejarah peradaban Islam. Jakarta: Wacana Ilmu.

Harild E. Mitzel, (Eds.). 1982. Encyclopedia of educational research. New York: A Division of Macmillan Publishing, Inc.

Harun Nasution. 1979. Islam ditinjau dari berbagai aspeknya. Jilid. I. Jakarta: UI Press.

Hasan Muarif Ambary. 1998. Menemukan peradaban jejak arkeologis dan historis Islam Indonesia. Jakarta: Logos Wacana Ilmu.

Hasan98.tripod.com/pendidik.htm.

http://www.google.com.

Ira M. Lapidus. 1999. Sejarah sosial umat Islam. Jakarta RajaGrafindo Persada.

Irfan Hielmy. 2000. Wancana Islam. Ciamis: Pusat Informasi Pesantren.

Ismail Hamid. 1985. Peradaban Melayu dan Islam. Kuala Lumpur: Fajar Bakti.

Kamus besar bahasa Indonesia. 1988. Jakarta: Departemen Pendidikan dan Kebudayaan Republik Indonesia.

Kamus Dewan (edisi keempat). 2010. Kuala Lumpur: Dewan Bahasa dan Pustaka.

M. Quraish Shihab. 1996. Wawasan al-Quran. Bandung: Mizan.

Mahmud Yunus. 1990. Sejarah pendidikan Islam. Jakarta: PT. Hidayakarya Agung.

Mahmudunnasir. 1981. Islam its concept and history. New Delhi: Kitab Bhavan.

Majalah Tajdid. 2009. Ciamis: Lembaga Penelitian dan Pengembangan.

Maksum. 1999. Madrasah sejarah \& perkembangannya. Jakarta: Logos.

Mastuki,. HS, El-sha, M. Ishom. 2006. Intelektualisme pesantren. Jakarta: Diva Pustaka.

Maulana Muhammad Ali. 1980. Islamologi (Dinul Islam). Jakarta: Ikhtiar Baru-Van Hoeve.

Mehdi Nakosteen. 1996. Kontribusi Islam atas dunia intelektual Barat; Deskripsi analisis abad keempat Islam. Terj. Joko S. Kahhar dan Supriyanto Abdullah. Surabaya: Risalah Gusti.

Mohd Taib Osman Etal. (ed). T.th. Tamadun Islam di Malaysia. Tanpa tempat dan penerbit.

Mohd Yusuf Ahmad. 2005. Pengajian Islam. Kuala Lumpur: Penerbit Universiti Malaya.

Muhammad Abduh. 1972. Al-Madaris al-tajhiziyat wa al-madaris al-aliya., dalam Imarah (ed.). al-A'mal al-kamil li al-imam Muhammad Abduh. Juz III. Beirut: al-Mu'assasah al-Arabiyah li al-Dirasah wa al-Nashar.

Muhammad al-Khatib. 1982. Al-'Usmaniyyah fi al-tarikh wa al-hadhrat. Kairo: alMarkaz al-Mishri.

Muhammad Syadid. 2001. Konsep pendidikan dalam al-Qur'an. Terj. Jakarta: Penebar Salam.

Muhammad Uthman El-Muhammady. 1977. Peranan Islam dalam Pembentukan Kebudayaan Melayu Islam dan kebudayaan Melayu. Kuala Lumpur: Kementerian Kebudayaan Belia dan Sukan.

Mustafa Haji Daud. 1997. Al-Quran sumber tamadun Islam. Kuala Lumpur: Jabatan Kemajuan Islam Malaysia (JAKIM).

Omar Muhammad al-Toumy al-Syaibani. 1975. Falsafah pendidikan Islam. Terj. Hasan Langgulung. Jakarta: Bulan Bintang.

P. Sibarani. Sejarah berdirinya pesantren. Diposting oleh Rulam, Tanggal 27 Desember 2013, Kategori: Artikel.

Philip K. Hitti. 1970. History of the Arabs. London: Macmillan.

Philip K. Hitti. 1970. The Arabs a short history. Terj. Ushuluddin Hutagalung. Bandung: Sumur. 
Samsul Nizar. 2011. Sejarah pendidikan Islam: Menelusuri jejak sejarah pendidikan era Rasulullah sampai Indonesia. Jakarta: Kencana.

Sayyed Qutb. 1979. Petunjuk sepanjang jalan. Kuala Lumpur: El-Ikhwan Enterprise.

Soekarno dan Ahmad Supadi. 1990. Sejarah dan filsafat pendidikan Islam. Bandung: Penerbit Angkasa Bandung.

Syafiyyur Rahman al-Mubarakfury. 2000. Sirah nabawiyah. Cet. Ke-9. Jakarta: Pustaka al-Kautsar.

Syed Muhammad Naquib al-Attas. 1992. Konsep pendidikan dalam Islam. Bandung: Mizan.

Van Donzel, E., et.al. 1978. The encyclopedia of Islam. Leiden: E.J. Brill.

Wahab Rochidin. 2004. Sejarah pendidikan Islam di Indonesia. Bandung: CV. Alfabeta. 